Flood Profiles in the Calapooya Creek Basin, Oregon By John Friday

U.S. GEOLOGICAL SURVEY OPEN-FILE REPORT $\mathbf{8 2 - 4 3 9}$

Prepared in cooperation with

DOUGLAS COUNTY 


\section{UNITED STATES DEPARTMENT OF THE INTERIOR}

JAMES G. WATT, Secretary

\section{GEOLOGICAL SURVEY}

Dallas L. Peck, Director

COVER PHOTOGRAPH: View of Calapooya Creek when looking downstream from the bridge on Highway 99 in Oakland. 


\section{CONTENTS}

Page

Abstract-1- 1

Introd uction- 1

Scope of study- 1

Basin characteristics- 3

Flood history 3

Anal ytical techniques-_- 4

Hydrol ogy

Hydraulics- 5

Floodway analysis-_- 6

Model verification- 8

Selected references- 9 


\section{ILLUSTRATIONS}

Page

Figure 1. Vicinity map showing location of map panels-_-_-_- 2

2. Flood-frequency curve for gaging

station 14-3207.00 4

3. Schematic floodway cross section-_ 7

4. Stage-discharge relation for gaging

station 14-3207.00-_- 8

5-16. Profiles of Calapooya Creek- 19-30

\section{TABLES}

Page

Table 1. Summary of discharge- 5

2. Calapooya Creek profile elevations- 10-13

3. Calapooya Creek floodway data-_- 14-18

Available separately

Map panels 1-7. Orthophoto map panels showing location of cross sections, 100-year flood boundaries, selected 100-year flood elevations, and designated floodway 


\section{CONVERSION TABLE}

[For the use of those readers who might prefer to use metric rather than inch-pound units]

$\begin{array}{lll}\text { MULTIPLY BY TO OBTAIN } & \text { BY }\end{array}$

Inch (in.)

25.4

Millimeter ( $\mathrm{mm})$

Foot $(f t)$

0.3048 Meter (m)

Mile (mi)

1.609 Kilometer $(\mathrm{km})$

Square mile $\left(\mathrm{mi}^{2}\right)$

2.59 Square kilometer $\left(\mathrm{km}^{2}\right)$

Cubic foot per second $\left(\mathrm{ft}^{3 / \mathrm{s}}\right)$

0.0283 Cubic meter per second $\left(\mathrm{m}^{3} / \mathrm{s}\right)$

\section{NOTE}

National Geodetic Vertical Datum of 1929 (NGVD of 1929): A geodetic datum derived from a general adjustment of the first-order level nets of both the United States and Canada, formerly called mean sea level. 


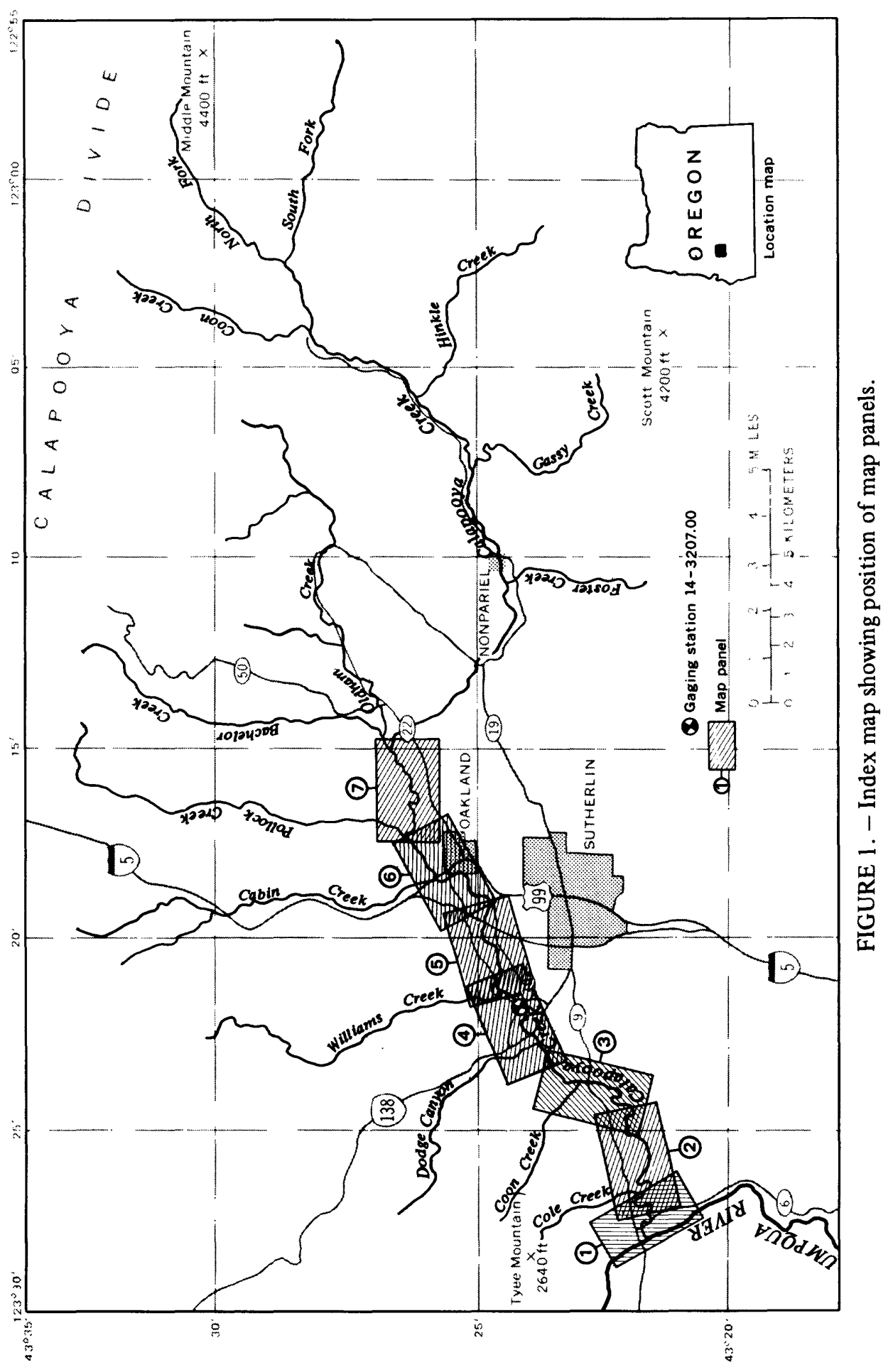




\title{
FLOOD PROFILES IN THE CALAPOOYA CREEK BASIN, OREGON
}

By John Friday

\begin{abstract}
Water-surface profiles were conputed for a 19.4-mile reach of Calapooya Creek in Douglas County, Oreg. The data will enable the county to evaluate flood hazards in the flood-prone areas in the reach. Profiles for floods having recurrence intervals of $2,10,50,100$, and 500 years are shown in graphic and tabular form. A floodway, allowing encroachment of the 100-year flood, was designed with a maximum 1.0-foot surcharge limitation. A profile for a flood that occurred in November 1961 is al so presented. All data were derived from a digital coinputer model developed for the study.
\end{abstract}

\section{INTRODUCTION}

This study was made at the request of the Douglas County water Resources Survey. The flood-profile data will enable the county to evaluate the flood hazards in the lower reaches of Calapooya Creek. A knowledge of these elevations and their related flood boundaries is essential for administering land-use measures in the flood plains. A well-managed flood plain can reduce the risk of losses of life and property by controlling the location of future developments in flood-prone areas.

Wherever possible, this study has been made conpatible with a Flood Insurance Study (FIS) completed for the unincorporated areas of Douglas County (U.S. Federal Emergency Management Agency, 1973). In that study, data for Calapooya Creek were derived by approximate methods, based in part on flood elevations computed in an earlier profile study of the Umpqua River (Oster, 1972). The data presented herein supersede the approximate study and follows a format suitable for a subsequent Flood Insurance Study should the need arise.

\section{SCOPE OF STUDY}

The study reach extends from the mouth of Calapooya Creek to a point 639 ft upstream from Oldham Creek (river mile 19.4). See figure 1. Water-surface elevations were conputed for floods that would occur on the average of once every 2, 10, 50, 100, and 500 years; a profile documenting a flood that occurred in November 1961 was al so a requirement of this study. A floodway analysis was made to determine the areas that must be kept free fram encroachment in order to pass the 100-year flood without exceeding a specified 1.0-foot surcharge.

The accuracy limit of all profile elevations is $+0.5 \mathrm{ft}$; all elevations are referenced to the National Geodetic Vertical Datum of 1929 (NGVD). 
Boundaries of the 100-year flood and the designated floodway are shown on orthophoto maps furnished by Douglas County (published separately). Also shown are elevations for the 100-year flood at selected locations. The relative position of the seven map panels are shown on the vicinity map in figure 1.

\section{BASIN CHARACTERISTICS}

Calapooya Creek is a tributary of the Uinpqua River and it originates at the Calapooya Divide, a mountain range dividing the Willamette and Umpqua River basins in western Oregon. The stream flows westerly in deep canyons until it reaches Oldham Creek at the upstrean end of the study area. No major tributaries enter the creek from the south downstream from that point. The main channel is entrenched in fertile alluvial valleys. The streambanks are covered with dense brush and trees and the flood plains are undulating pasture and farmlands interspersed with thickets of deciduous brush and trees.

Elevations range from $353 \mathrm{ft}$ at the bridge deck on County Road 6 near the mouth, to $4,400 \mathrm{ft}$ at Middle Mountain, the highest peak in the basin. The steep terrain in the upper basin is heavily forested, but clearcut areas with dense brush are numerous. The relief in the lower basin is more subdued; vegetation consists of coniferous and deciduous trees, brush, and grasslands.

The hydrologic soil group throughout the basin is in the SteiwerSutherlin Association and is classified as Group C (U.S. Soil Conservation Service, 1968). Such soil has a slow infiltration rate when thoroughly wetted, and surface runoff is high.

The only incorporated area in the 247-square-mile basin is the community of Oakland which has a population of 890 ( see Oregon Bl ue Book, 1981-1982, State of Oregon, 1981). The stream flows through the western edge of the city, but the business district and suburban areas are located well above the flood plain.

\section{FLOOD HISTORY}

Flooding is a common occurrence in the Calapooya Creek basin. High-intensity winter rainstorms result fron the passage of Pacific stgrm fronts that move quickly through the area. Flows in excess of $20,000 \mathrm{ft}^{3} / \mathrm{s}$ will inundate the flood plains because the channel gradient is very low.

The highest peak flow recorded at a gaging station located at the covered bridge on County Road 10 (station 14-3207.00) occurred in November 1961. The discharge of $26,600 \mathrm{ft} / \mathrm{s}$, with an estimated recurrence interval of about 15 years, caused flooding in many areas throughout the basin. Population densities at the time were light, and flood damage is unknown.

The most extensive flooding occurred in December 1964 when backwater from the Umpqua River extended $3.4 \mathrm{mi}$ up the Calapooya Creek channel. The recurrence interval for the Umpqua flood is estimated to be about 100 years. The concordant flow in Calapooya Creek (peaking 5 hours earlier) was 21,000 $\mathrm{ft}^{3} / \mathrm{s}$, an 8-year flood. Estimated flood danage totaling $\$ 183,000$ involved 27 hames and included extensive siltation of agricultural lands (U.S. Army Corps of Engineers, 1966a). 


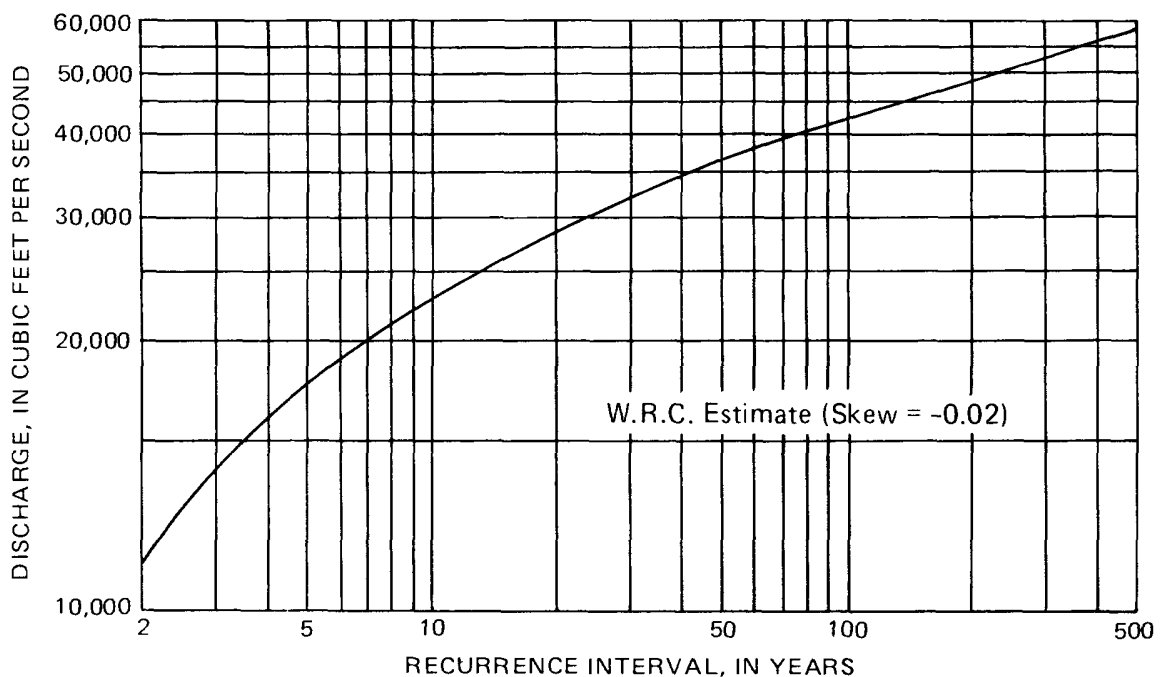

FIGURE 2. - Flood-frequency curve for gaging station 14-3207.00. Calapooya Creek near Oakland, Oreg. (1956-80).

\section{ANALYTICAL TECHNIQUES}

\section{Hydrology}

To determine the flood hazards in the study reach, it was necessary to estimate the magnitude of floods that would be equaled or exceeded on the average of once every 2, 10, 50, 100, and 500 years. The reciprocal of each of these recurrence intervals indicates the exceedance probability of the event (expressed as a percent chance of their occurring in any given year). For example, a 50-year flood would have a 2 percent chance of being equaled or exceeded during the year $(1 / 50=0.02)$.

In 1977, the U.S. Water Resources Council (WRC) established guidelines to be used for estimating such floods whenever 10 or inore years of recorded peak-flow data were available. Station 14-3207.00, Calapooya Creek near Oakland, Oreg.. with 24 years of peak data, was therefore used in the recommended log-Pearson Type III probability distribution with a generalized skew coefficient determined from WRC Bulletin 17-A. No outliers were detected, and the resultant discharges were not adjusted for expected probability. The WRC frequency curve is shown in figure 2.

Peak discharges at selected points in the study reach are shown in table 1. Each of the design discharges at the gaging station was adjusted for tributary inflow by using the transfer formula:

$$
Q_{u}=Q_{g}\left(A_{u} / A_{g}\right)^{a}
$$

where

$Q_{u}=$ unknown discharge at the tributary, in $\mathrm{ft}^{3} / \mathrm{s}$

$Q_{g}=$ discharge at the gaging station, in $\mathrm{ft}^{3} / \mathrm{s}$

$A_{u}=$ drainage area at the tributary, in $\mathrm{mi}^{2}$

$\mathrm{A}_{\mathrm{g}}=$ drainage area at the gaging station, in $\mathrm{mi}^{2}$, and

a = variable exponent derived by regression analysis and presented in the western Oregon flood-frequency report (Harris and others, 1979). 
Table 1. - Summary of discharge used to estimate flood-profile elevations

\begin{tabular}{|l|c|c|c|c|c|c|c|}
\hline & Lrainage & \multicolumn{5}{|c|}{ Peak discharge, in cubic feet per second } \\
\cline { 5 - 8 } & $\begin{array}{c}\text { area } \\
\left(\mathrm{mi}^{2}\right)\end{array}$ & $\begin{array}{c}\text { 2-year } \\
\text { flood }\end{array}$ & $\begin{array}{c}10 \text {-year } \\
\text { flood }\end{array}$ & $\begin{array}{c}50 \text {-year } \\
\text { flood }\end{array}$ & $\begin{array}{c}100 \text {-year } \\
\text { flood }\end{array}$ & $\begin{array}{c}500 \text {-year } \\
\text { flood }\end{array}$ & $\begin{array}{c}1961 \\
\text { flood }\end{array}$ \\
\hline At confluence with Umpqua River & 247 & 12,600 & 26,400 & 41,400 & 48,500 & 67,000 & 30,700 \\
Downstream from Dodge Canyon & 224 & 11,600 & 24,300 & 37,900 & 44,400 & 61,300 & 28,200 \\
At gaging station 14-3207.00 & 210 & 11,000 & 22,900 & 35,800 & 41,900 & 57,800 & 26,600 \\
Upstream from Williams Creek & 193 & 10,200 & 21,300 & 33,200 & 38,800 & 53,500 & 24,700 \\
Upstream from Cabin Creek & 162 & 8,800 & 18,200 & 28,300 & 33,200 & 45,600 & 21,200 \\
Downstream from 0ldham Creek & 144 & 7,950 & 16,400 & 25,400 & 29,800 & 41,000 & 19,100 \\
\hline
\end{tabular}

The transfer formula is normally limited to drainage areas that are within 5 to 25 percent of that at the gaging station. The extreme upper reach of Calapooya Creek slightly exceeds this limitation, but to attain consistency in flow distribution, the transfer formula was used throughout the reach.

\section{Hydraulics}

Water-surface elevations were computed at all cross sections by using the USGS computer program E-431 (Shearinan, 1976). The program used in the digital model computes energy losses between sections, using conservationof-energy equations (step-backwater analysis). The hydraulic model requires measurements of channel cross sections, bridge and dam geanetries, and an evaluation of the roughness of the main channel and flood plains. Cross-section definition and bridge geometries were furnished by Douglas County. The location of each of the 111 sections is shown on the seven or thophoto maps also provided by the county.

Cross sections 1 to 8 are on the Umpqua River flood plain. Initial elevations for the 2- and 10-year floods were considered to be unaffected by backwater and were derived using a slope-conveyance study at section 1. Initial elevations for each of the higher floods were determined at section 8 and represent concurrent flooding of the Umpqua River. The water-surface elevations for cross sections 1 to 8 represent the energy slope of the Umpqua River as computed in the Douglas County Flood Insurance Study (see U.S. Federal Einergency Managenent Agency, 1978). 
When the Umpqua River is high, flow can enter the Calapooya Creek flood plain via two swales in the pasture between County Road 6 and the river. When the Umpqua River is low, flows in the swales reverse direction, allowing a part of the Calapooya flow to bypass sections 1 to 6 . Because the floodway analysis involves a 100-year flood event unaffected by backwater, it was necessary to determine the extent of bypass flow before a valid initial elevation could be computed at section 8. A composite stage-discharge relation combining culvert and road overflow could not be made because the downstream channel slope would not support a critical-depth condition. It was therefore necessary to establish a stage-discharge relation at the outlet of each culvert, using a profile-convergence study at sections 301 through 305 as described by Bailey and Ray (1966). A trial-and-error solution was then made in which an assumed discharge at the mouth, plus the bypass flow, equaled the desired flow at section 8 .

A similar bypass-flow situation occurred at the railroad-bridge embankment in north Oakland. Profile elevations at cross sections 79 to 82 are based on only that part of the total flow passing through the bridge opening ( see map panel 6 ).

The roughness coefficients (Manning's "n" values) were assigned to segments of each cross section and applied to the reach of channel extending halfway to the next nearest section. Coefficients ranged from 0.035 to 0.050 in the main channel and from 0.032 to 0.080 in the flood plains. An exception to this range in values occurred when cross sections were necessarily extended up the channel of a tributary (see sections 43 and 44 , map panel 4). Unrealistically high coefficients $(0.150)$ were assigned to reduce the conveyance in those areas having adverse flow directions.

Friction losses are, in part, a function of the distance between cross sections (subreaches) as measured along the center line of the channel. When extensive bank overflow occurs at a sharply meandering channel, it is necessary to adjust this distance to better represent the effective subreach length. The adjustment is made by computing a weighted value based on the straight-line distance between the centroids of the conveyance of the flood plain(s) and the actual distance and conveyance of the main channel. Conveyance is a term used to indicate the ability of the channel to transmit flows. The distances shown in the tables and figures of this report apply to the main channel even though adjusted values were used in the model.

The profile elevations at each cross section are shown in table 2; a plot of the profiles is shown in figures 5-16.

\section{FLOODWAY ANALYSIS}

Encroachment on flood plains causes an increase in flood elevations, thereby increasing the flood hazard in areas upstream from the encroachment. Flood-plain management involves weighing the benefits from potential development against the increase in flood hazards. To assist planners in this phase of flood-plain management, a floodway analysis was made that presented an allowable encroachment of the 100-year flood that would not cause more than a 1.0-foot increase in water-surface elevations (surcharge) in the main channel. 


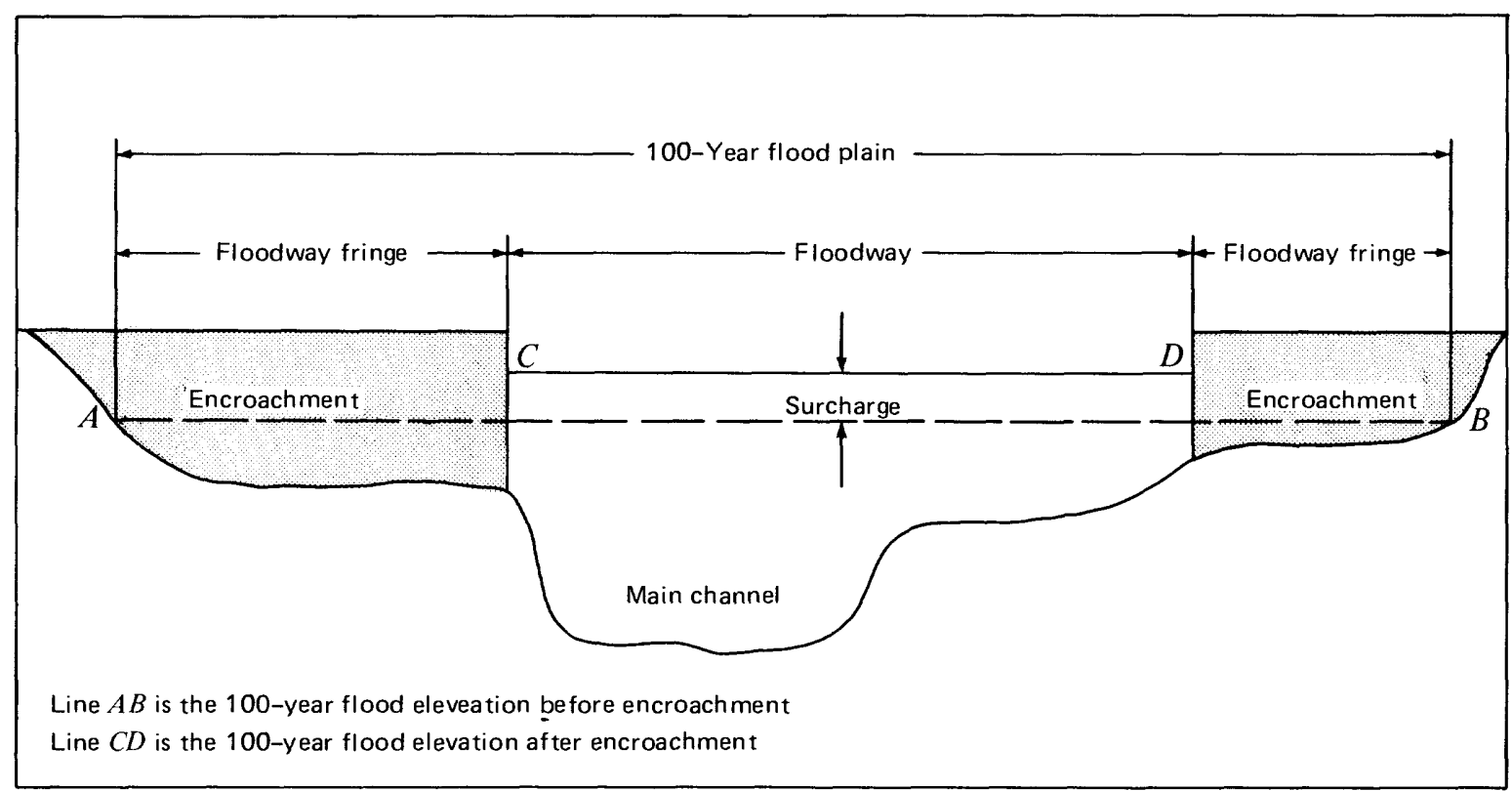

FIGURE 3. - Schematic floodway cross section.

\section{FLOODWAY ANALYSIS - Continued}

A floodway is that part of a stream that must be kept free from encroachment in order to pass a 100-year flood without exceeding the specified surcharge. Ideally, a floodway should be designed based on an equal reduction of conveyance from the flood plains on each side of the stream. However, this is not possible where peak flows are totally contained by one of the banks. Also, a floodway based solely on a desired surcharge often results in unrealistic and unmanageable boundaries. In such cases, uniformity of floodway widths becones an equally important factor.

The area between the floodway and the boundary of the 100-year flood is termed "the floodway fringe." This is the part of the flood plain that could be completely obstructed without causing an excessive surcharge. Figure 3 shows the relationship between the floodway and the floodway fringe.

The floodway on Calapooya Creek began at cross-section 8 because it was necessary to merge the floodway boundaries with those already established in the Douglas County FIS. Some modification in the location of the Umpqua River boundaries was necessary, but any change in published surcharges and related data is mininal. The location of the floodway is shown on map panels 1 to 7; the results of the encroachment of each cross section are shown in table 3: 


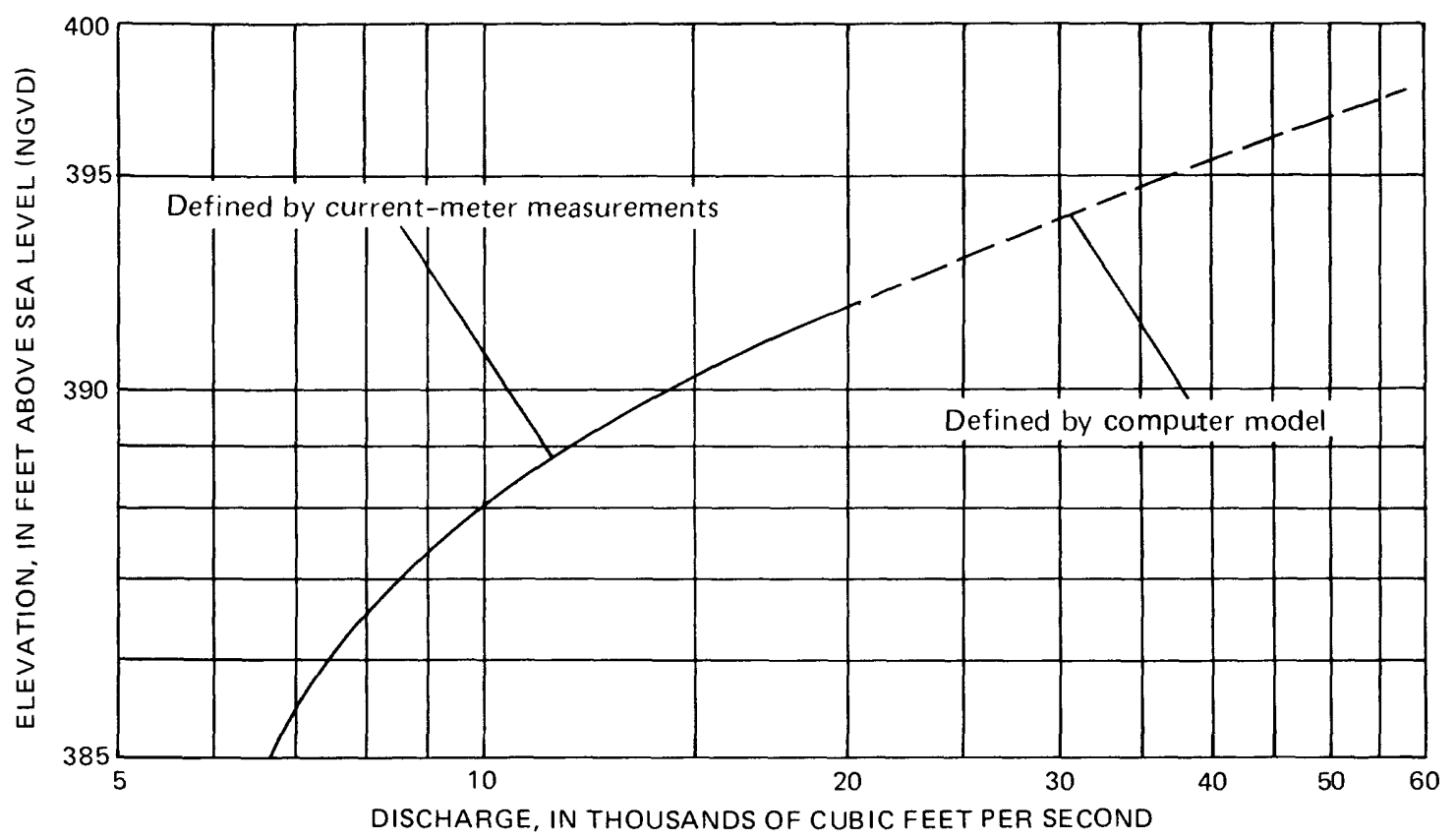

FIGURE 4. - State-discharge relation for gaging station 14-3207.00. Calapooya Creek near Oakland, Oreg. (1956-80).

\section{MODEL VERIFICATION}

Many high-water marks were documented following the flood of December 1964. The discharge of $21,000 \mathrm{ft}^{3 / \mathrm{s}}$ has an 8 -year recurrence interval, and the conputed 10-year profile elevations agreed well with many marks. Some marks could not be used because they reflected backwater from debris obstructions; others were questionable because of their uncertain location.

An indirect measurement of peak flow was made at the bridge on Highway 138 following the flood of Decenber 1955. The computed discharge of 20,300 $\mathrm{ft}^{3} / \mathrm{s}$ was used to define the upper linit of a stage-discharge relation at the gaging station $0.9 \mathrm{mi}$ upstream. The stage-discharge relation developed at cross section 45 in the computer nodel agreed within $0.1 \mathrm{ft}$ of the headwater elevation and discharge for that flood.

The sinulated profile for the flood of November 1961 is based on a discharge of $26,600 \mathrm{ft}^{3} / \mathrm{s}$, a 15-year flood. The computed elevation at cross section 49 was $0.4 \mathrm{ft}$ higher than the recorded elevation at the gage which is located in a draw-down area behind a bridge pier.

The stage-discharge relation at the gaging station is shown in figure 4. Current-ineter measurements have indicated that a progressive scouring of the control has occurred since the station was established in 1956. The stage of the 2-year flood is questionable because there are no recent measurements to indicate that this scouring trend is continuing. The computer model provided a reasonable extension of the rating curve and is believed to be well within the accuracy limits required in this study.

There are no flood-control structures or levees in the basin. All the data presented in this report are based on field conditions that existed when the aerial photographs were taken (Nov. 5, 1980). The study presents unobstructed flow conditions, although debris problems have occurred in the past. Changes in drainage structures and channel alinements or the addition of levees could alter the profile elevations presented herein. 


\section{SELECTED REFERENCES}

Bailey, J. F., and Ray, H. A., 1966, Definition of stage-di scharge relation in natural channels by step-backwater analysis: U.S. Geological Survey Water-Supply Paper 1869-A, 24 p.

Bodhaine, G. L., 1968, Measurement of peak discharge of culverts by indirect methods: U.S. Geological Survey Techniques of Water-Resources Investigations, book 3, chap. A3, $60 \mathrm{p}$.

Carrigan, P. H., and Kirby, William, 1976, Log-Pearson Type III flood-frequency analysis using guidelines of the Water Resources Council (Program J-407): U.S. Geological Survey WATSTORE Users Guide, v. 4, chap. I, $57 \mathrm{p}$.

Harris, D. D., Hubbard, L. L., and Hubbard, L. E., 1979, Magnitude and frequency of floods in western Oregon: U.S. Geological Survey Open-File Report 79-553, 35 p.

Hulsing, Harry, 1967, Measurement of peak discharge at dams by indirect methods: U.S. Geoloical Survey Techniques of Water-Resources Investigations, book 3, chap. A5, $29 \mathrm{p}$.

Matthai, H. F., 1967, Measurement of peak discharge at width contractions by indirect methods: U.S. Geological Survey Techniques of Water-Resources Investigations, book 3, chap. A4, $44 \mathrm{p}$.

Oster, E. A., 1972, pt. 1 of Flood profiles in the Umpqua River basin, Oregon: U.S. Geological Survey open-file report, 119 p.

Shearman, J. O., 1976, Computer applications for step-backwater and floodway analyses: U.S. Geologicl Survey Open-File Report 76-499, $103 \mathrm{p}$.

State of Oregon, Secretary of State, 1981, Oregon blue book, 1981-1982: $404 \mathrm{p}$.

U.S. Army Corps of Engineers, 1966a, postflood report, December 1964 and January 1965 floods. Portland District, U.S. Army Corps of Engineers, $237 \mathrm{p}$.

1966b, Flood plain information, interim report, Douglas County, Oregon: U.S. Army Corps of Engineers, $32 \mathrm{p}, 3 \mathrm{pl}$.

U.S. Federal Emergency Management Agency, 1978, Flood insurance study, Douglas County (unincorporated), Oregon: U.S. Federal Emergency Management Agency, $50 \mathrm{p}$.

U.S. Soil Conservation Service, 1968, Columbia North Pacific framework study, Soils Associations, Coastal subregion 10: U.S. Soil Conservation Service, fig. 45:

U.S. Water Resources Council, 1977, Guidelines for determining flood-flow frequency: U.S. Water Resources Council Bulletin 17-A, 26 p. 
Table 2.--Calapooya Creek profile elevations

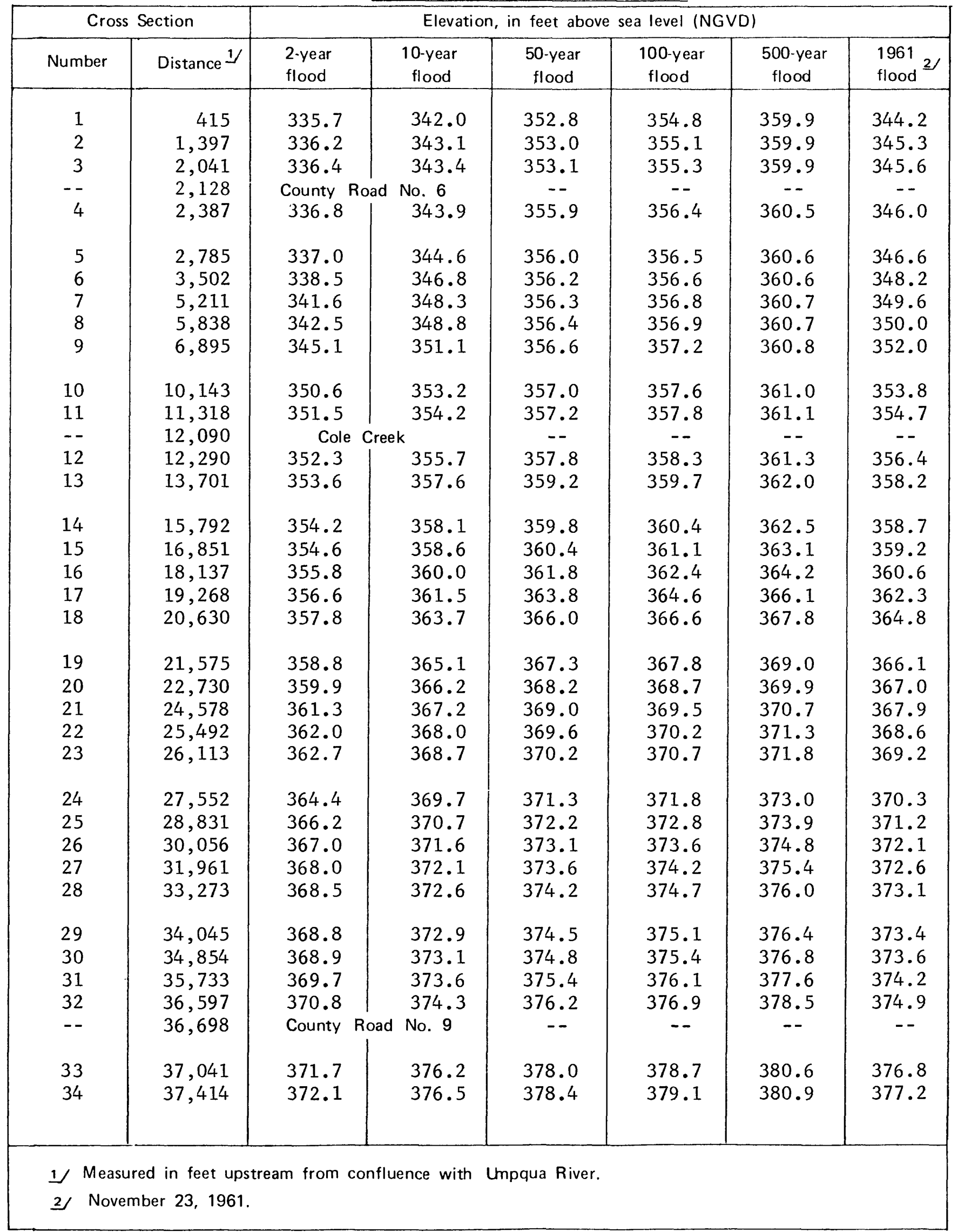


Table 2.--Calapooya Creek profile elevations--Continued

\begin{tabular}{|c|c|c|c|c|c|c|c|}
\hline \multicolumn{2}{|c|}{ Cross Section } & \multicolumn{6}{|c|}{ Elevation, in feet above sea level (NGVD) } \\
\hline Number & Distance ${ }^{1 /}$ & $\begin{array}{l}\text { 2-year } \\
\text { flood }\end{array}$ & $\begin{array}{c}10-y e a r \\
\text { flood }\end{array}$ & $\begin{array}{c}50 \text {-year } \\
\text { flood }\end{array}$ & $\begin{array}{l}\text { 100-year } \\
\text { flood }\end{array}$ & $\begin{array}{l}500 \text {-year } \\
\text { flood }\end{array}$ & $\begin{array}{l}1961 \\
\text { flood }\end{array}$ \\
\hline-- & 37,860 & \multicolumn{2}{|c|}{ Coon Creek } & -- & -- & -- & -- \\
\hline 35 & 38,306 & 373.3 & 377.4 & 379.2 & 379.9 & 381.7 & 378.0 \\
\hline 36 & 39,122 & 373.9 & 378.3 & 380.2 & 380.9 & 382.6 & 378.9 \\
\hline 37 & 39,896 & 374.6 & 379.3 & 381.4 & 382.2 & 384.1 & 380.0 \\
\hline 38 & 40,829 & 375.4 & 380.7 & 383.0 & 383.7 & 385.5 & 381.5 \\
\hline 39 & 41,710 & 376.6 & 382.2 & 384.5 & 385.3 & 387.1 & 383.0 \\
\hline 40 & 42,577 & 377.9 & 383.1 & 385.4 & 386.2 & 388.0 & 383.9 \\
\hline 41 & 43,530 & 379.4 & 384.5 & 386.8 & 387.6 & 389.4 & 385.3 \\
\hline 42 & 44,955 & 381.3 & 385.9 & 388.0 & 388.9 & 390.7 & 386.6 \\
\hline-- & 45,430 & \multicolumn{2}{|c|}{ Dodge Canyon } & -- & -- & -- & -- \\
\hline 43 & 47,857 & 382.2 & 386.5 & 388.7 & 389.6 & 391.5 & 387.2 \\
\hline 44 & 48,117 & 382.3 & 386.6 & 388.8 & 389.7 & 391.6 & 387.3 \\
\hline-- & 48,261 & \multicolumn{2}{|c|}{ State Highway No. 138} & -- & -- & -- & -- \\
\hline 45 & 48,565 & 382.5 & 387.1 & 390.0 & 390.9 & 392.6 & 388.1 \\
\hline 46 & 50,011 & 383.2 & 387.6 & 390.4 & 391.3 & 393.0 & 388.5 \\
\hline 47 & 51,109 & 384.0 & 388.4 & 391.0 & 391.9 & 393.6 & 389.2 \\
\hline 48 & 52,842 & 387.1 & 391.9 & 394.6 & 395.4 & 397.3 & 392.9 \\
\hline 49 & 53,208 & 388.1 & 392.3 & 394.9 & 395.7 & 397.6 & 393.2 \\
\hline-- & 53,262 & \multicolumn{5}{|c|}{ County Road No.10 and gaging station $14-3207.00$ (14 feet downstream) } & -- \\
\hline 50 & 53,472 & 388.6 & 393.0 & 395.7 & 396.5 & 398.3 & 394.0 \\
\hline 51 & 54,386 & 389.1 & 393.5 & 396.3 & 397.2 & 399.0 & 394.5 \\
\hline 52 & 55,406 & 390.3 & 394.4 & 397.1 & 397.9 & 399.7 & 395.3 \\
\hline 53 & 56,524 & 392.0 & 395.7 & 398.0 & 398.8 & 400.6 & 396.5 \\
\hline 54 & 57,711 & 392.6 & 396.4 & 398.6 & 399.3 & 401.1 & 396.9 \\
\hline-- & 58,020 & \multicolumn{2}{|c|}{ Williams Creek } & -- & -- & -- & -- \\
\hline 55 & 59,582 & 393.6 & 397.4 & 399.5 & 400.2 & 401.8 & 398.1 \\
\hline 56 & 60,804 & 394.8 & 398.4 & 400.2 & 400.8 & 402.4 & 399.0 \\
\hline 57 & 61,850 & 395.6 & 399.4 & 401.0 & 401.6 & 403.0 & 399.9 \\
\hline 58 & 62,869 & 397.1 & 401.6 & 403.0 & 403.4 & 404.6 & 402.1 \\
\hline 59 & 63,879 & 398.4 & 403.6 & 405.4 & 406.0 & 407.4 & 404.2 \\
\hline 60 & 64,941 & 399.4 & 404.8 & 407.0 & 407.7 & 409.1 & 405.6 \\
\hline 61 & 66,225 & 401.0 & 405.8 & 407.9 & 408.6 & 410.1 & 406.5 \\
\hline 62 & 67,111 & 401.8 & 406.3 & 408.5 & 409.3 & 410.9 & 407.0 \\
\hline 63 & 67,668 & 402.0 & 406.4 & 408.6 & 409.4 & 411.0 & .407 .1 \\
\hline 64 & 68,217 & 402.4 & 406.6 & 408.9 & 409.7 & 411.4 & 407.4 \\
\hline-- & 68,383 & \multicolumn{2}{|c|}{ Interstate Highway I-5 } & -- & -- & -- & -- \\
\hline 65 & 68,768 & 403.2 & 408.2 & 411.5 & 412.8 & 416.1 & 409.3 \\
\hline 66 & 69,446 & 404.4 & 408.8 & 411.9 & 413.2 & 416.3 & 409.8 \\
\hline
\end{tabular}


Table 2.--Calapooya Creek profile elevations--Continued

\begin{tabular}{|c|c|c|c|c|c|c|c|}
\hline \multicolumn{2}{|c|}{ Cross Section } & \multicolumn{6}{|c|}{ Elevation, in feet above sea level (NGVD) } \\
\hline Number & Distance $1 /$ & $\begin{array}{l}2 \text {-year } \\
\text { flood }\end{array}$ & $\begin{array}{c}10 \text {-year } \\
\text { flood }\end{array}$ & $\begin{array}{l}50 \text {-year } \\
\text { flood }\end{array}$ & $\begin{array}{l}\text { 100-year } \\
\text { flood }\end{array}$ & $\begin{array}{l}500 \text {-year } \\
\text { flood }\end{array}$ & $\begin{array}{l}1961 \\
\text { flood }\end{array}$ \\
\hline 67 & 70,351 & 407.6 & 410.6 & 412.8 & 413.9 & 416.8 & 411.2 \\
\hline 68 & 71,270 & 408.6 & 411.3 & 413.4 & 414.4 & 417.2 & 411.9 \\
\hline 69 & 71,885 & 409.0 & 411.8 & 413.7 & 414.7 & 417.4 & 412.3 \\
\hline 70 & 73,017 & 410.1 & 412.8 & 414.6 & 415.5 & 417.9 & 413.4 \\
\hline 71 & 73,887 & 410.6 & 413.4 & 415.2 & 416.1 & 418.3 & 414.0 \\
\hline 72 & 74,973 & 411.9 & 415.2 & 417.2 & 418.0 & 420.0 & 415.8 \\
\hline 73 & 76,082 & 412.9 & 416.8 & 419.2 & 420.1 & 422.2 & 417.6 \\
\hline 74 & 76,705 & 413.1 & 417.0 & 419.5 & 420.4 & 422.5 & 417.8 \\
\hline 75 & 77,730 & 413.8 & 417.5 & 419.9 & 420.8 & 422.9 & 418.2 \\
\hline 76 & 78,403 & 414.4 & 418.0 & 420.3 & 421.2 & 423.3 & 418.7 \\
\hline-- & 78,483 & \multicolumn{2}{|c|}{ U.S. Highway No. 99} & -- & -- & -- & -- \\
\hline 77 & 78,617 & 415.4 & 418.8 & 421.0 & 421.7 & $\therefore 23.4$ & 419.5 \\
\hline 78 & 79,298 & 416.9 & 421.3 & 424.6 & 425.9 & 429.0 & 422.4 \\
\hline 79 & 80,007 & 417.4 & 421.9 & 425.1 & 426.4 & 429.4 & 422.8 \\
\hline 80 & 80,254 & 417.4 & 421.8 & 425.1 & 426.4 & 429.4 & 422.8 \\
\hline 81 & 80,608 & 418.6 & 423.3 & 426.0 & 427.1 & 429.8 & 424.2 \\
\hline-- & 80,708 & \multicolumn{2}{|c|}{ Cabin Creek } & -- & -0 & -- & -- \\
\hline 82 & 80,867 & 419.5 & 424.2 & 427.2 & 428.1 & 430.4 & 425.1 \\
\hline-- & 80,913 & \multicolumn{2}{|c|}{ Southern Pacific Railroad } & - & -- & -- & -- \\
\hline 83 & 81,024 & 419.8 & 424.6 & 427.7 & 428.8 & 431.3 & 425.6 \\
\hline 84 & 81,115 & 419.8 & 424.6 & 427.7 & 428.8 & 431.3 & 425.6 \\
\hline 85 & 81,769 & 420.0 & 424.7 & 427.8 & 428.9 & 431.3 & 425.7 \\
\hline 86 & 82,664 & 421.1 & 425.0 & 427.9 & 429.0 & 431.4 & 425.9 \\
\hline 87 & 83,371 & 421.6 & 425.4 & 428.1 & 429.2 & 431.6 & 426.2 \\
\hline 88 & 84,058 & 423.4 & 427.0 & 429.2 & 430.2 & 432.3 & 427.7 \\
\hline 89 & 84,764 & 424.9 & 428.6 & 430.6 & 431.6 & 433.6 & 429.3 \\
\hline 90 & 85,475 & 425.5 & 429.2 & 431.4 & 432.4 & 434.5 & 430.0 \\
\hline 91 & 86,226 & 426.1 & 430.2 & 432.6 & 433.6 & 435.1 & 431.0 \\
\hline 92 & 86,884 & 426.5 & 430.6 & 433.1 & 434.2 & 436.5 & 431.5 \\
\hline 93 & 87,571 & 427.2 & 431.4 & 434.2 & 435.4 & 437.9 & 432.4 \\
\hline-- & 87,590 & \multicolumn{2}{|c|}{ Pollock Creek } & -- & -- & -- & .- \\
\hline 94 & 88,232 & 427.8 & 432.0 & 434.7 & 435.8 & 438.4 & 432.9 \\
\hline 95 & 89,691 & 429.4 & 433.3 & 436.2 & 437.3 & 440.0 & 434.3 \\
\hline 96 & 90,320 & 429.6 & 433.5 & 436.3 & 437.5 & 440.1 & 434.4 \\
\hline 97 & 91,158 & 430.8 & 434.9 & 437.4 & 438.5 & 440.8 & 435.7 \\
\hline 98 & 92,031 & 432.3 & 436.4 & 439.1 & 440.0 & 441.7 & 437.3 \\
\hline 99 & 93,210 & 434.1 & 438.0 & 440.6 & 441.4 & 443.0 & 438.9 \\
\hline 100 & 94,290 & 435.3 & 438.9 & 441.6 & 442.4 & 444.2 & 439.8 \\
\hline
\end{tabular}


Table 2.--Calapooya Creek profile elevations--Continued

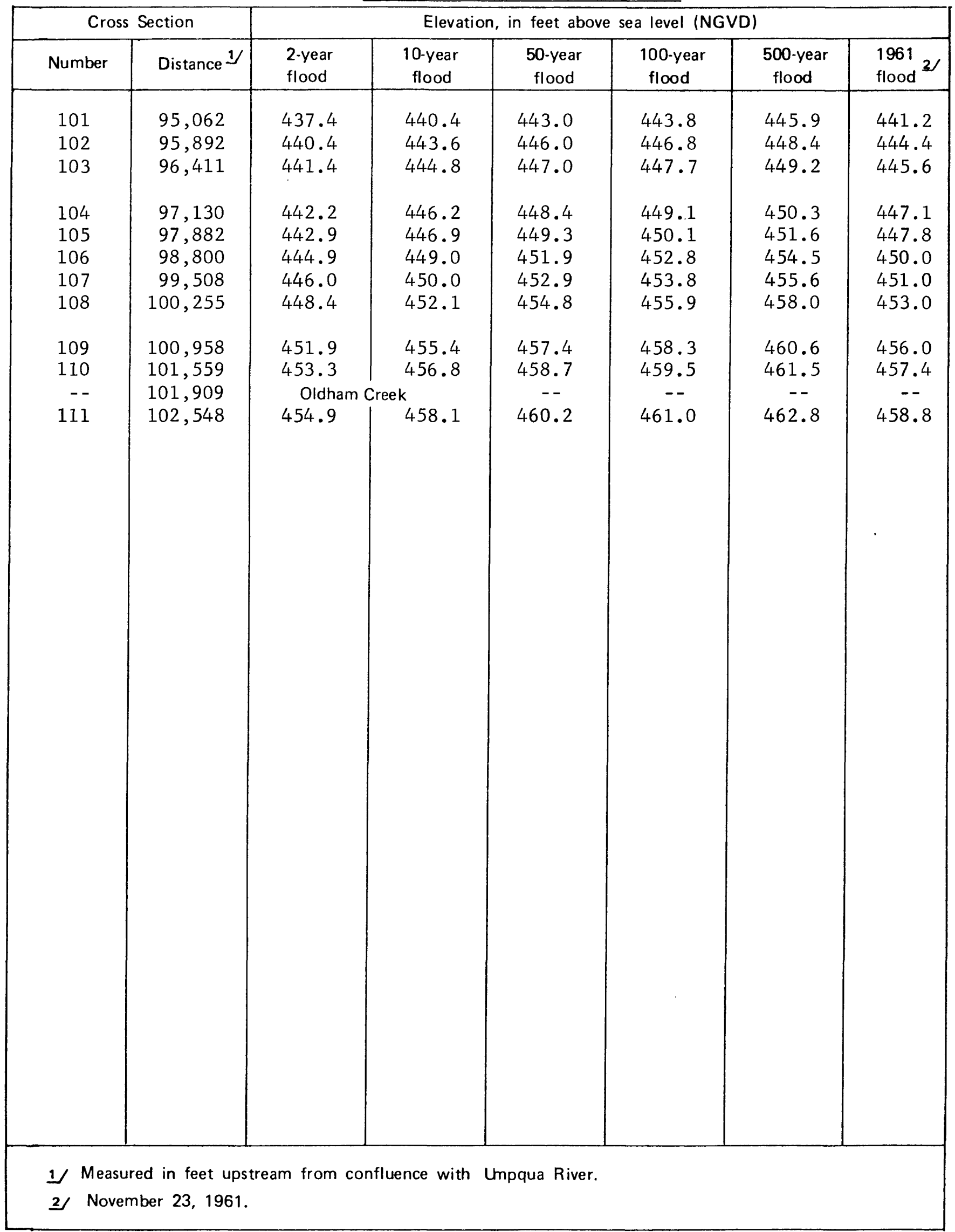




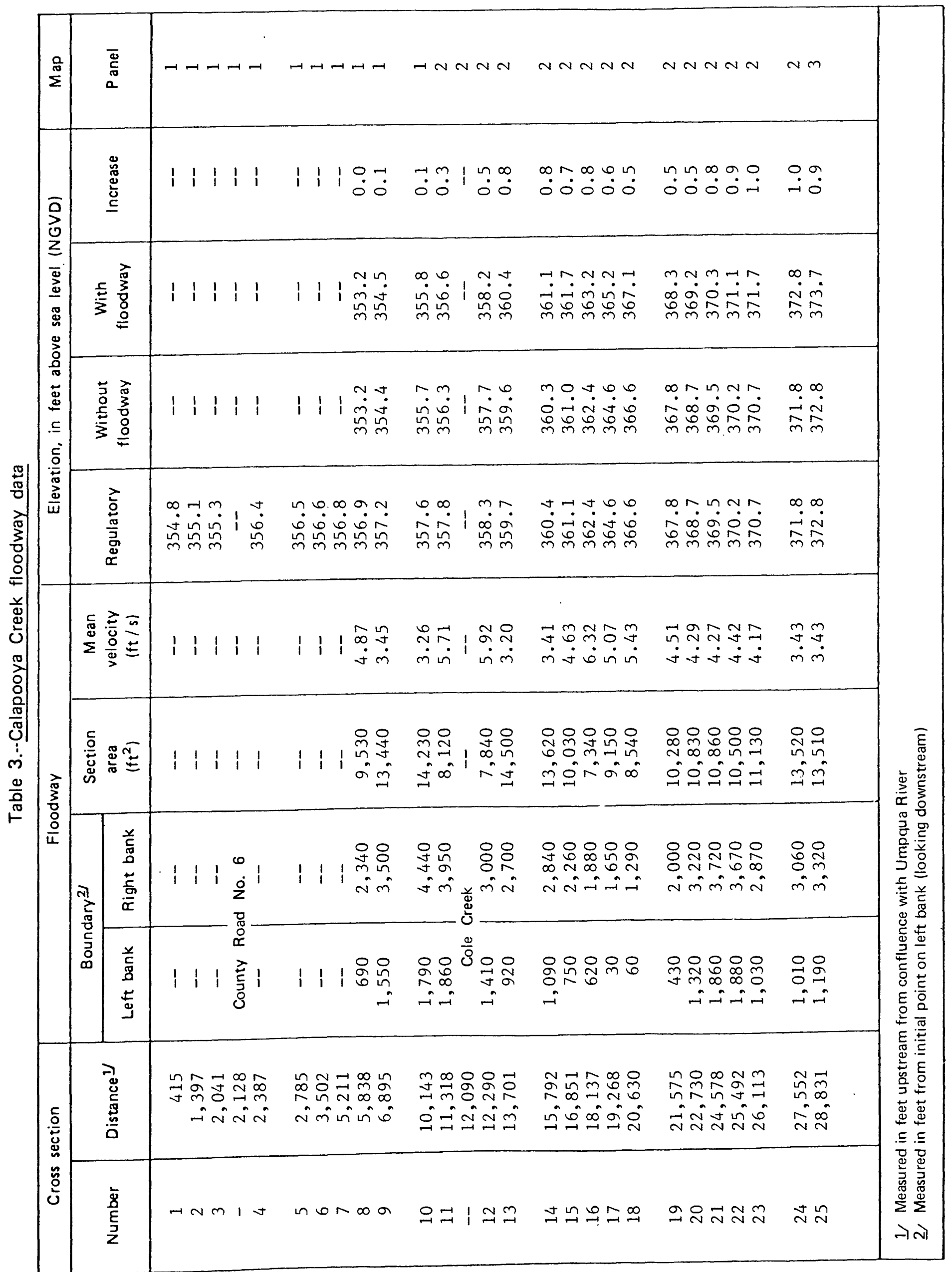




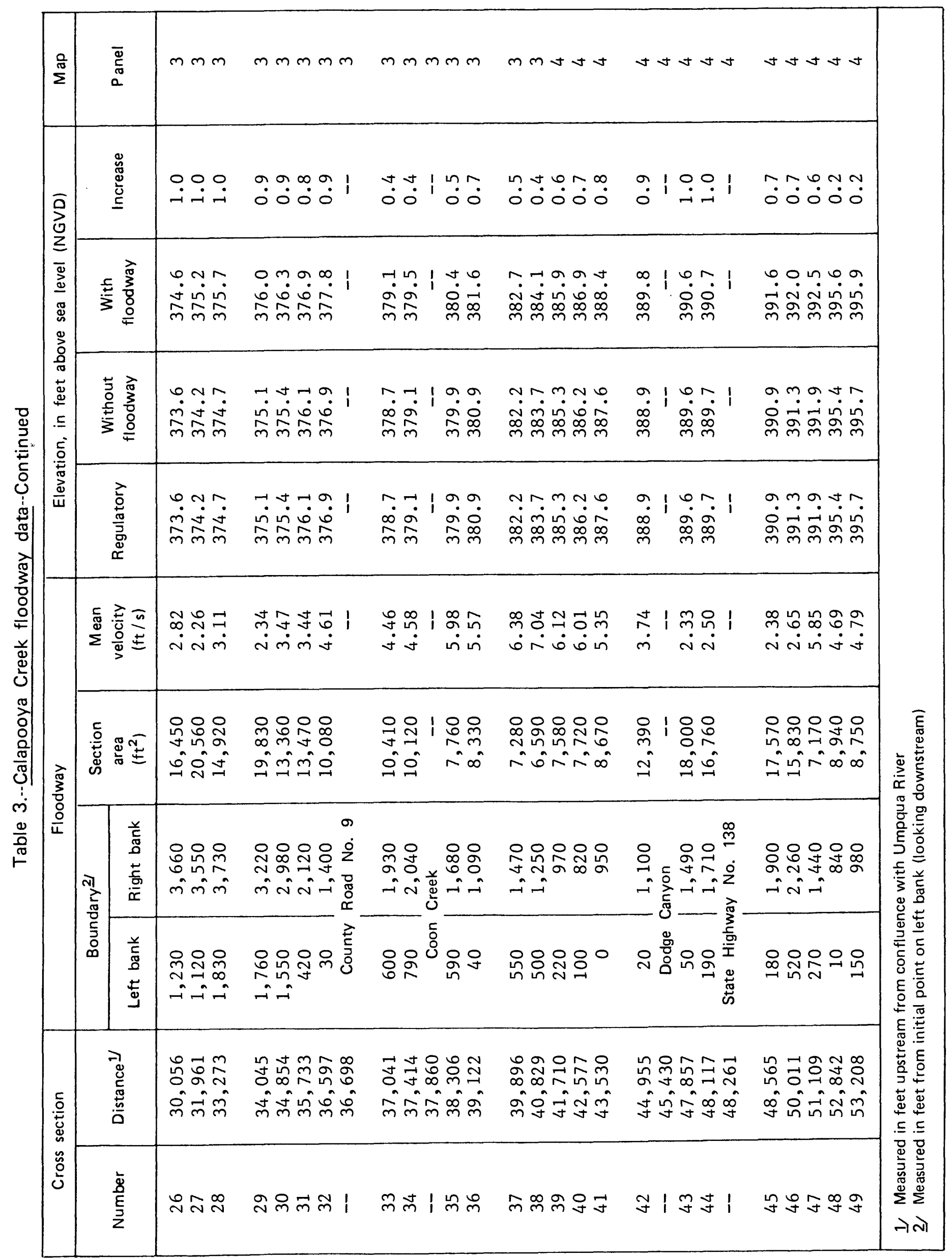




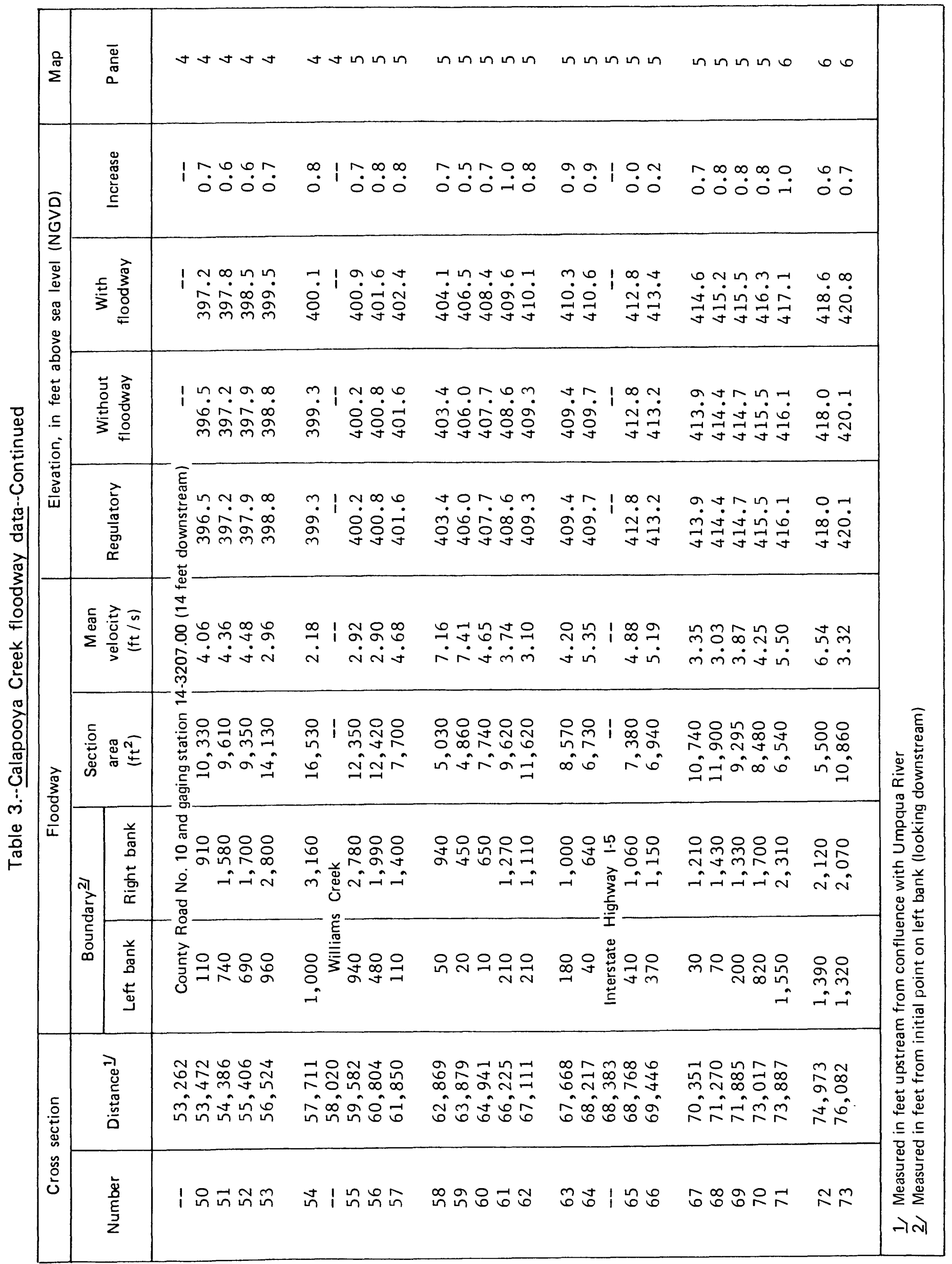




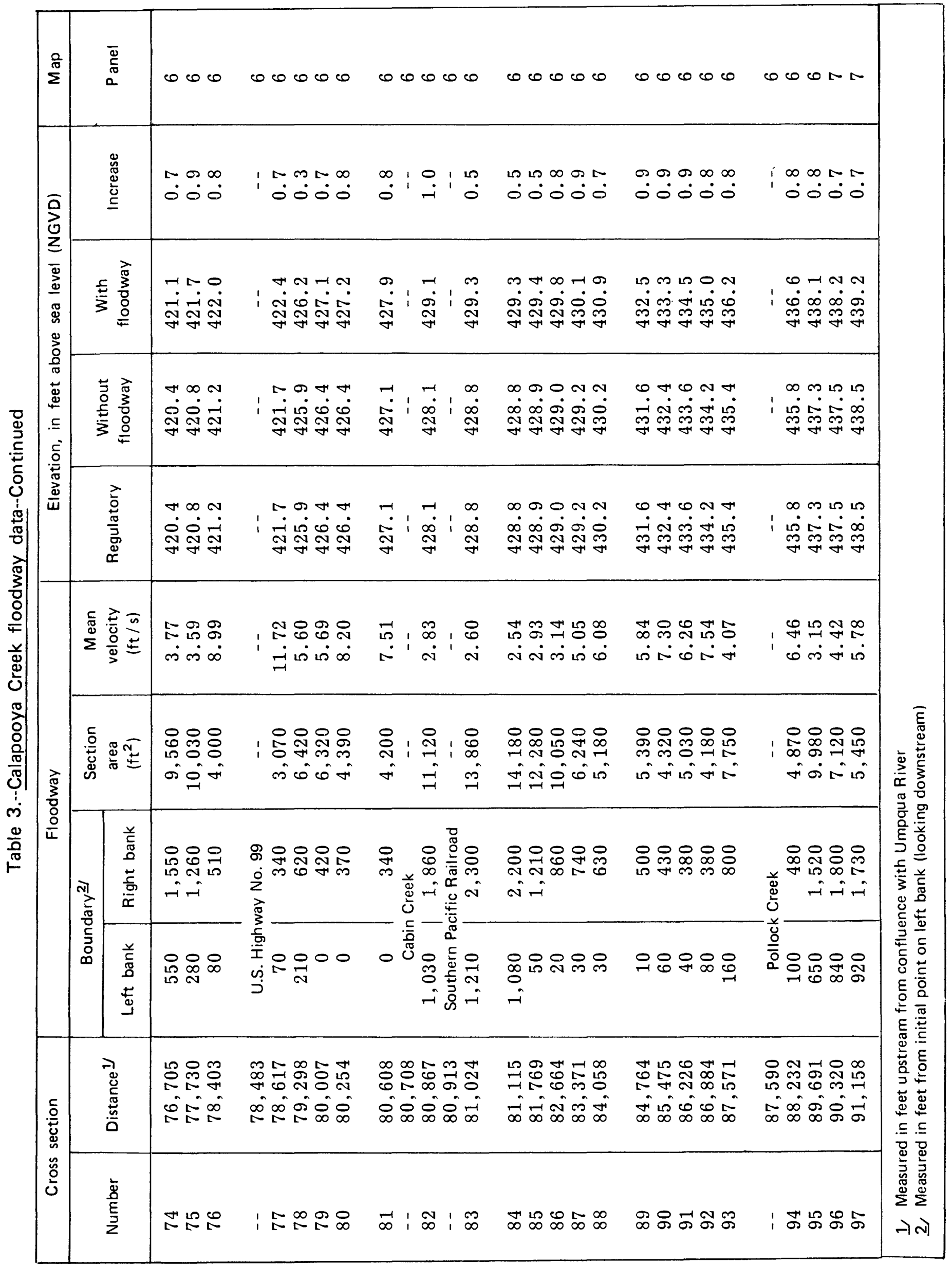




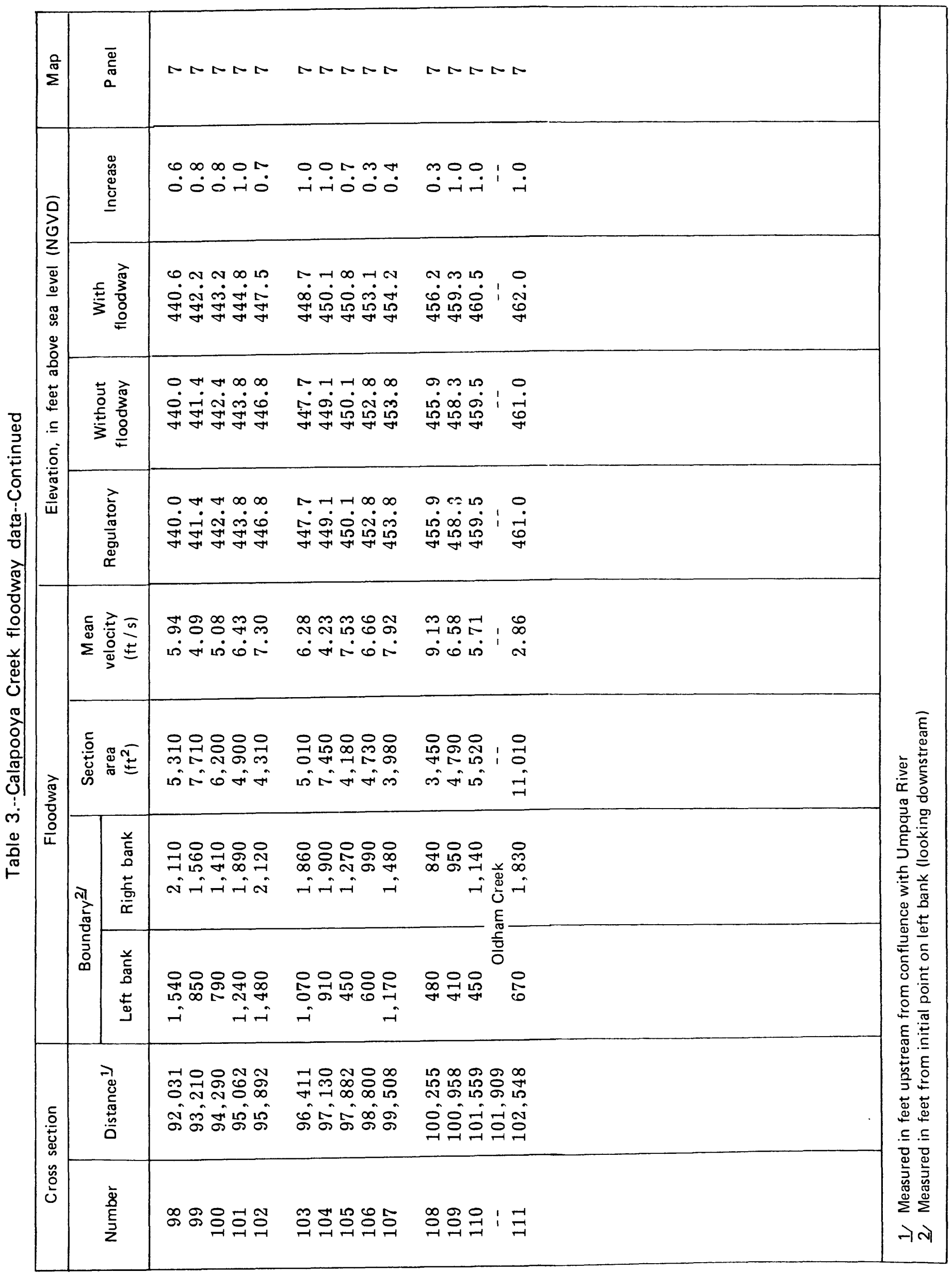




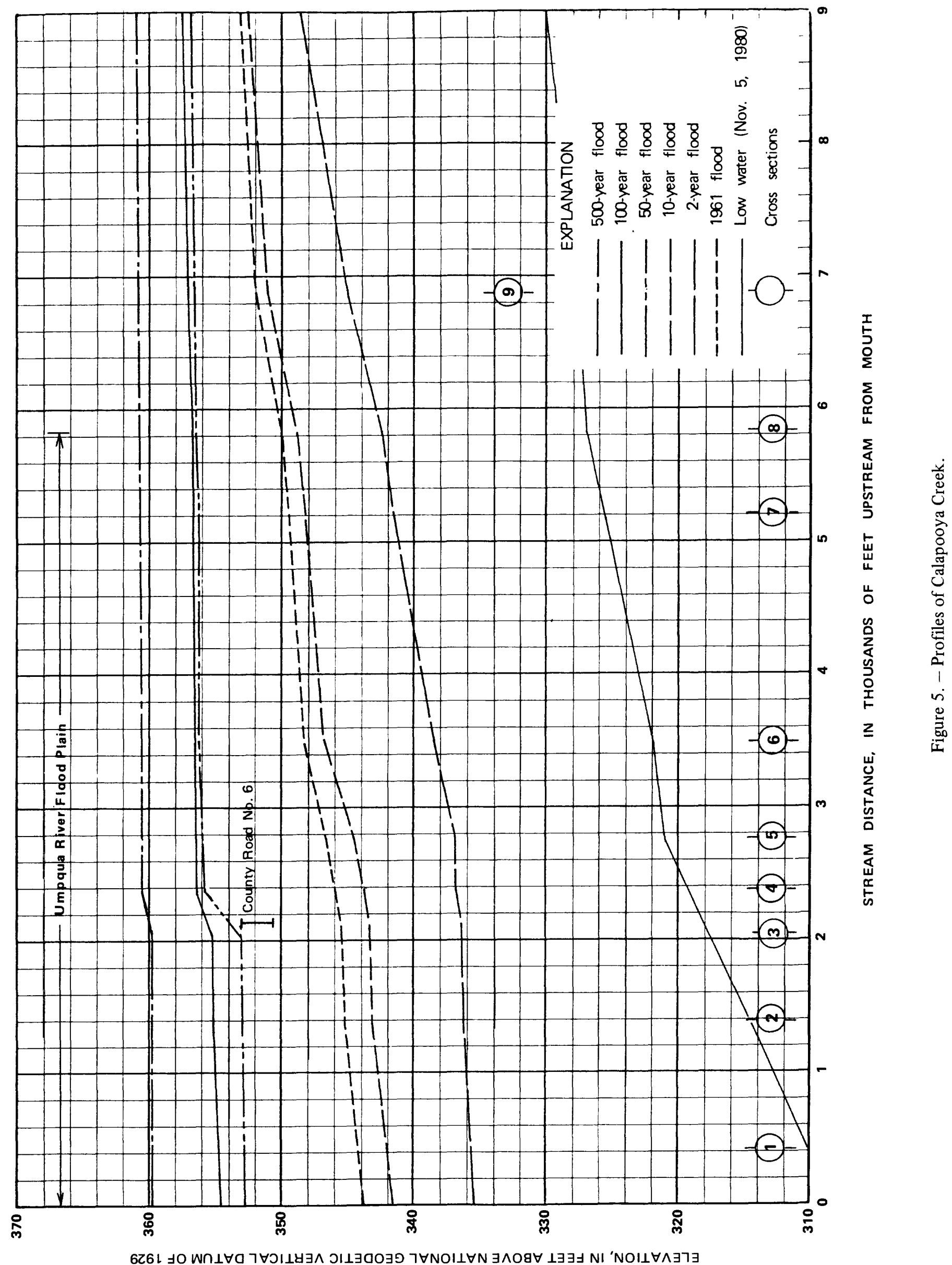




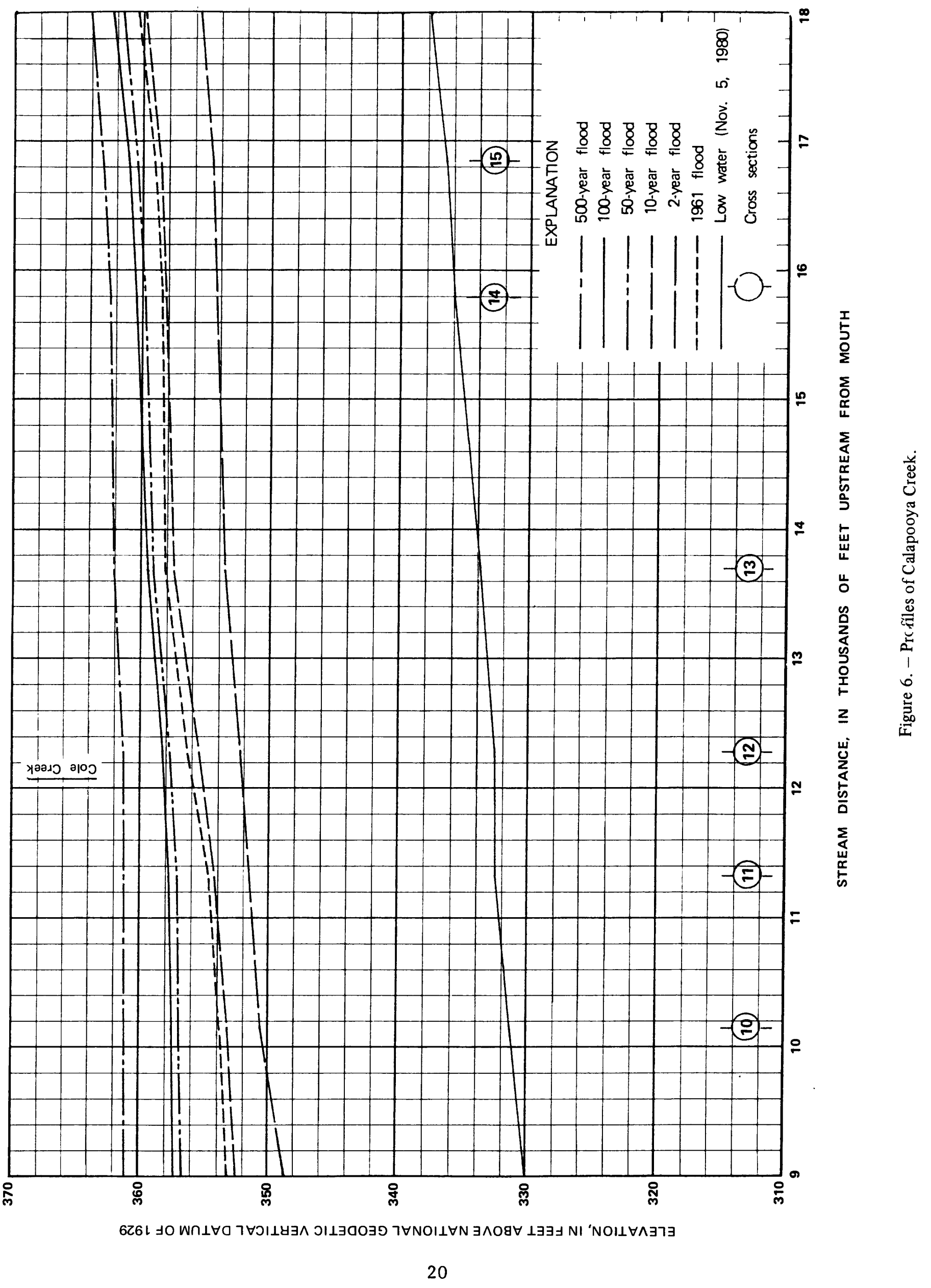




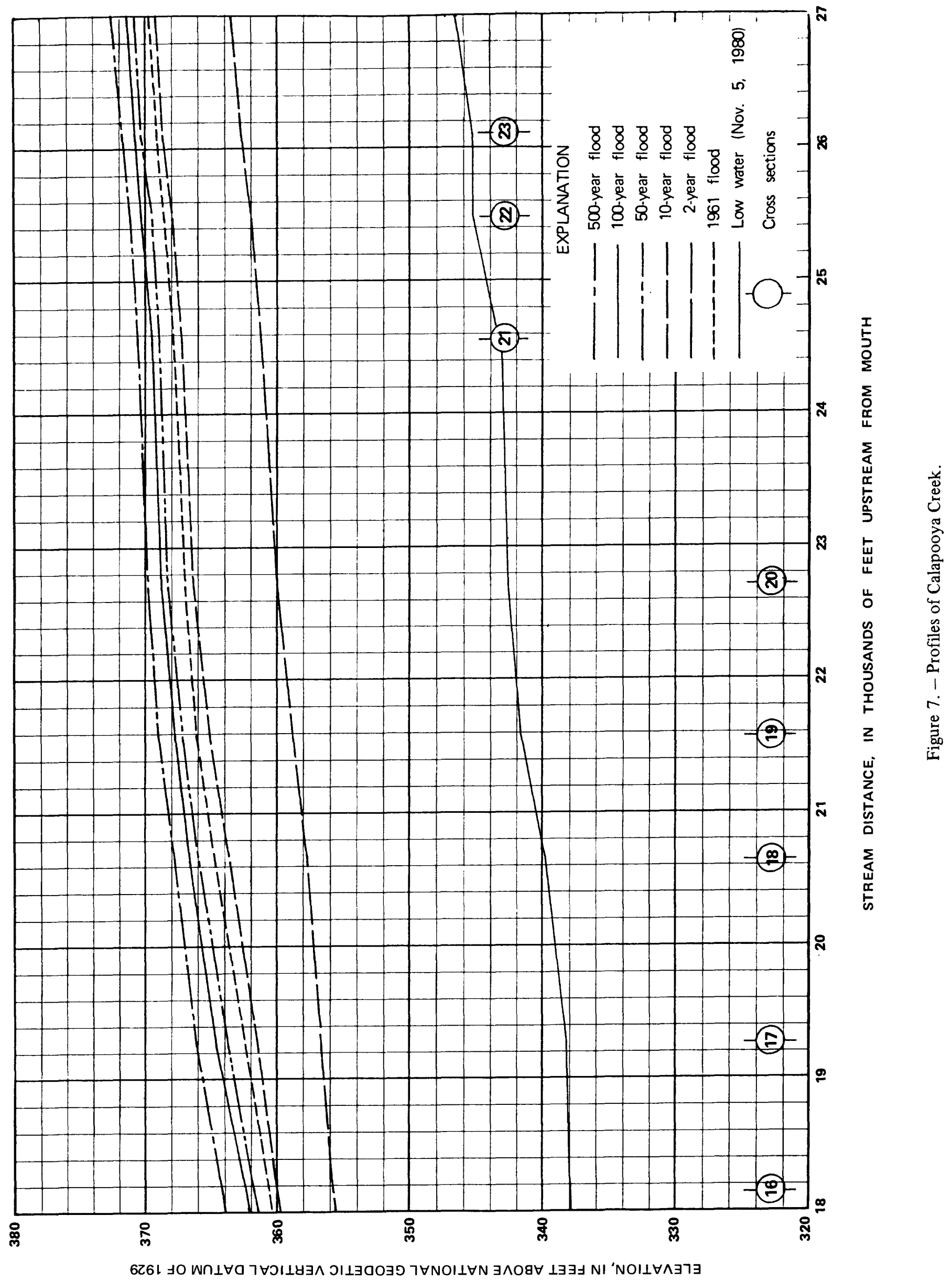




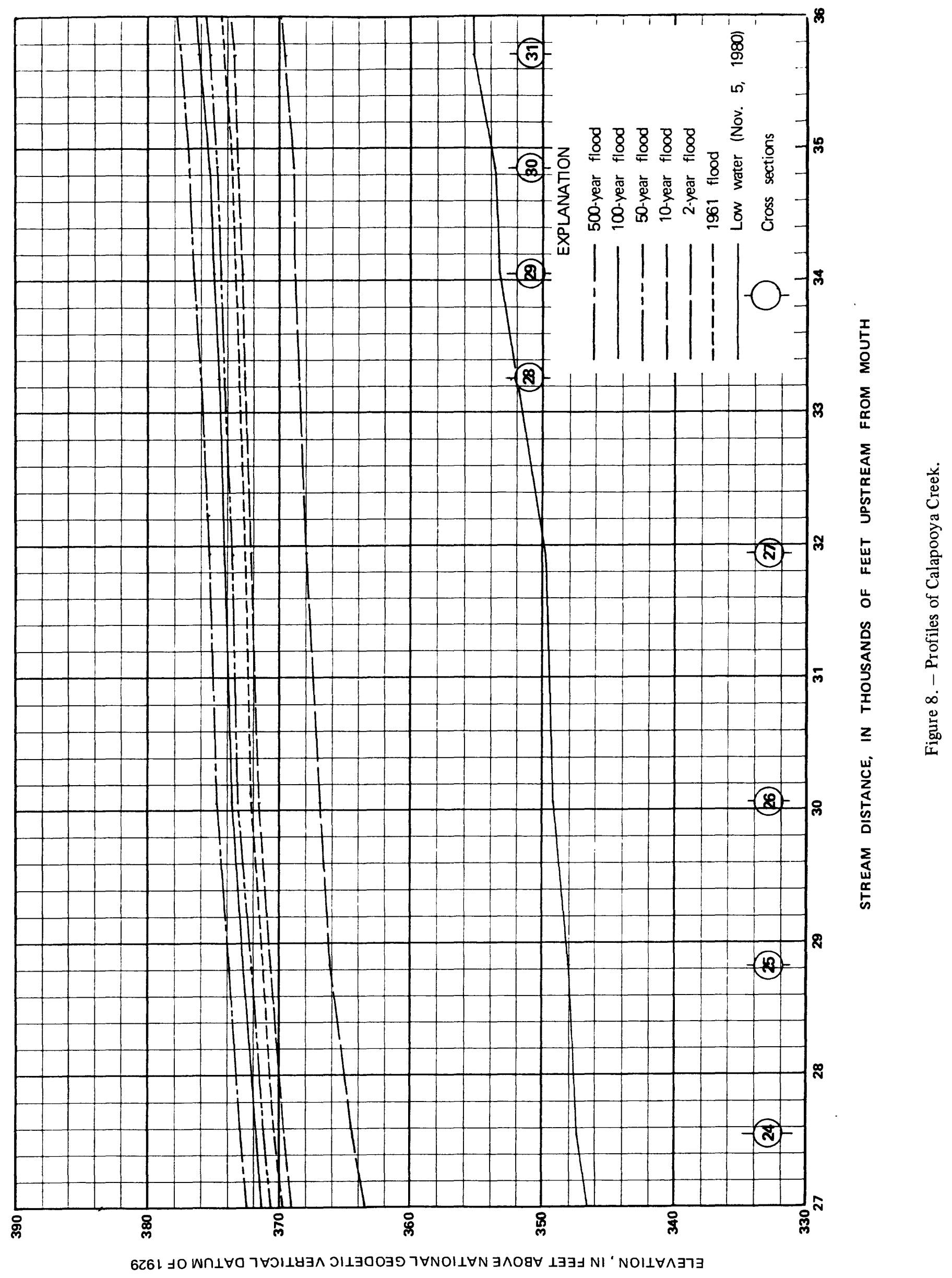




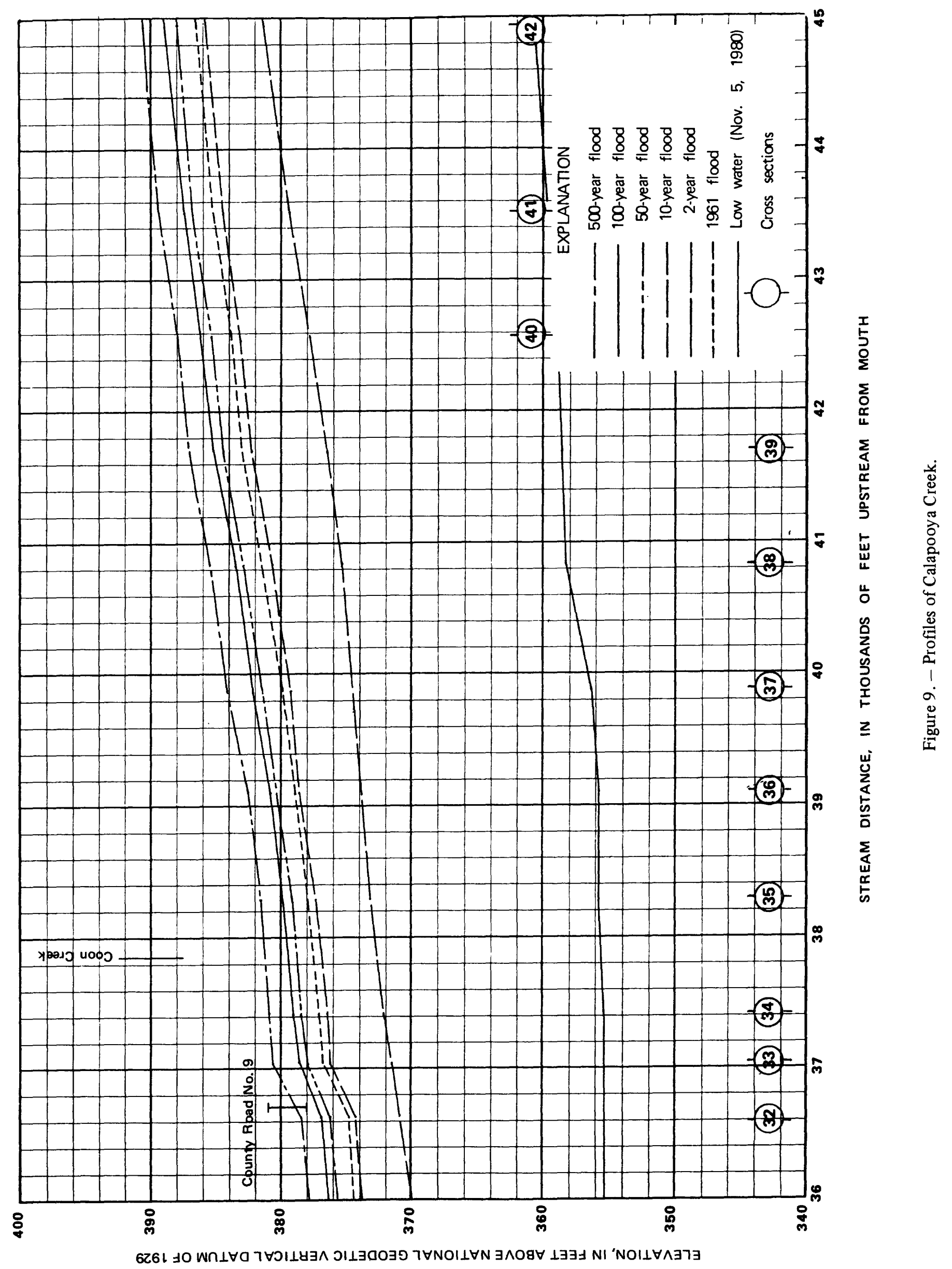




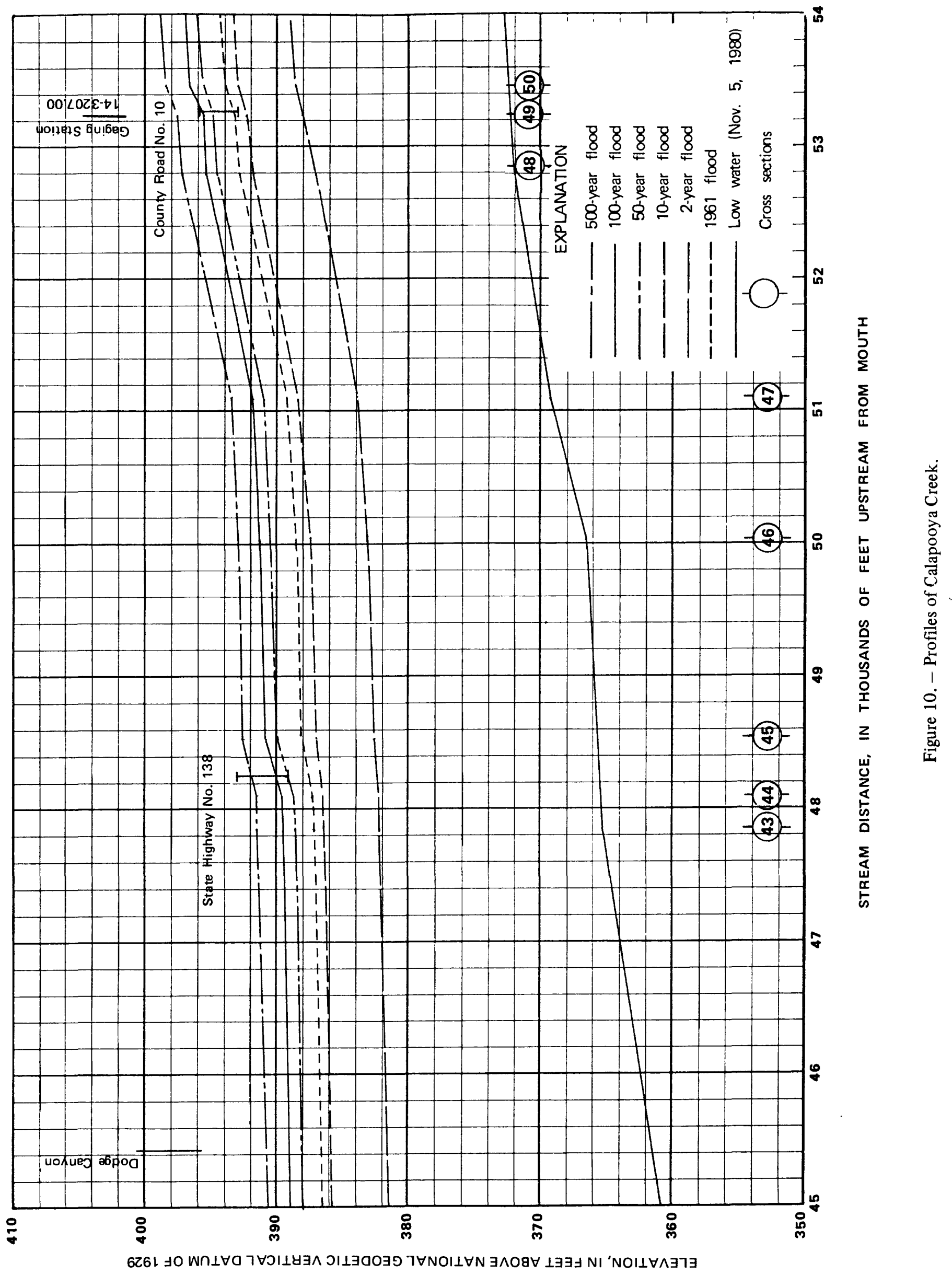




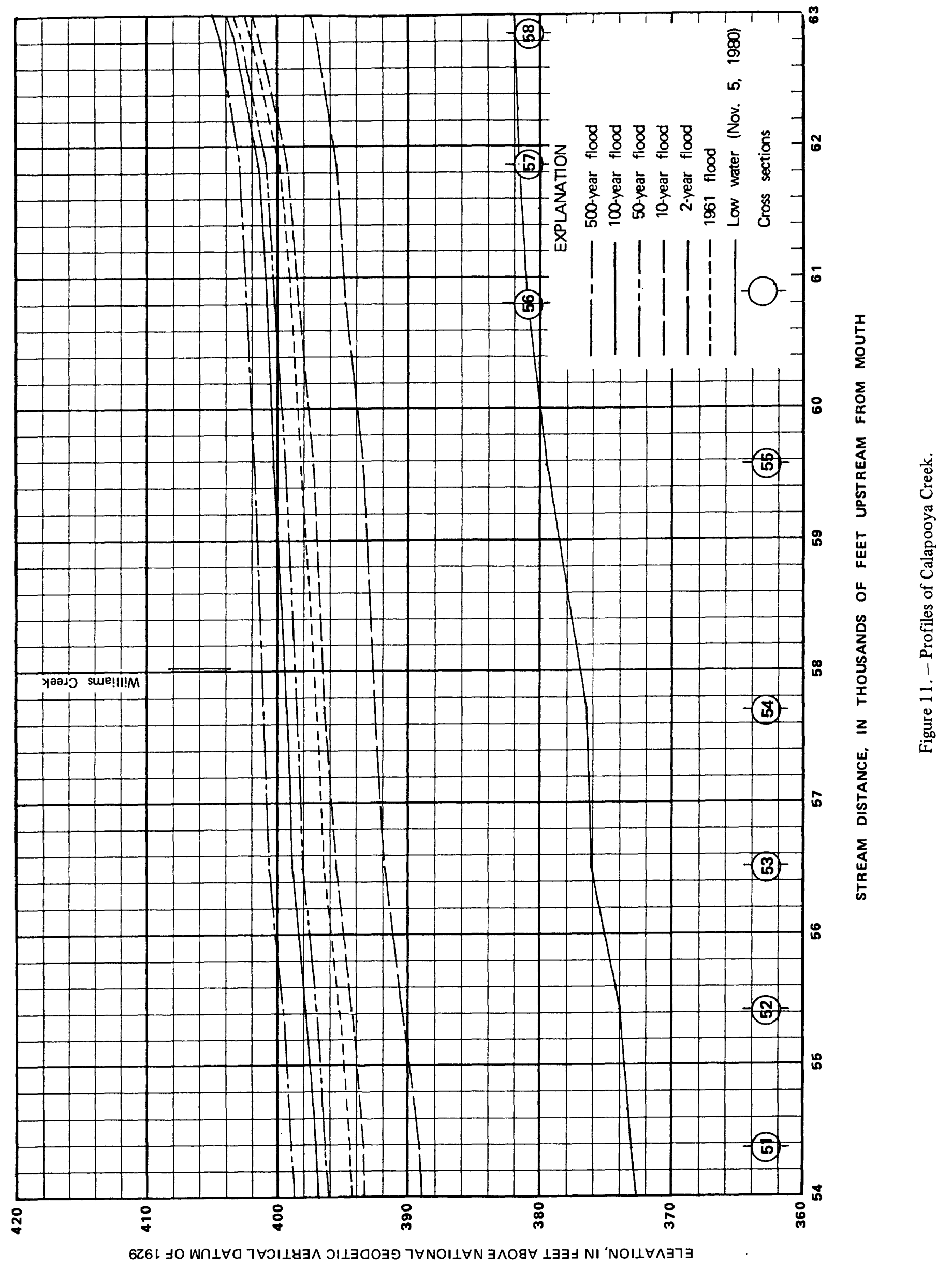




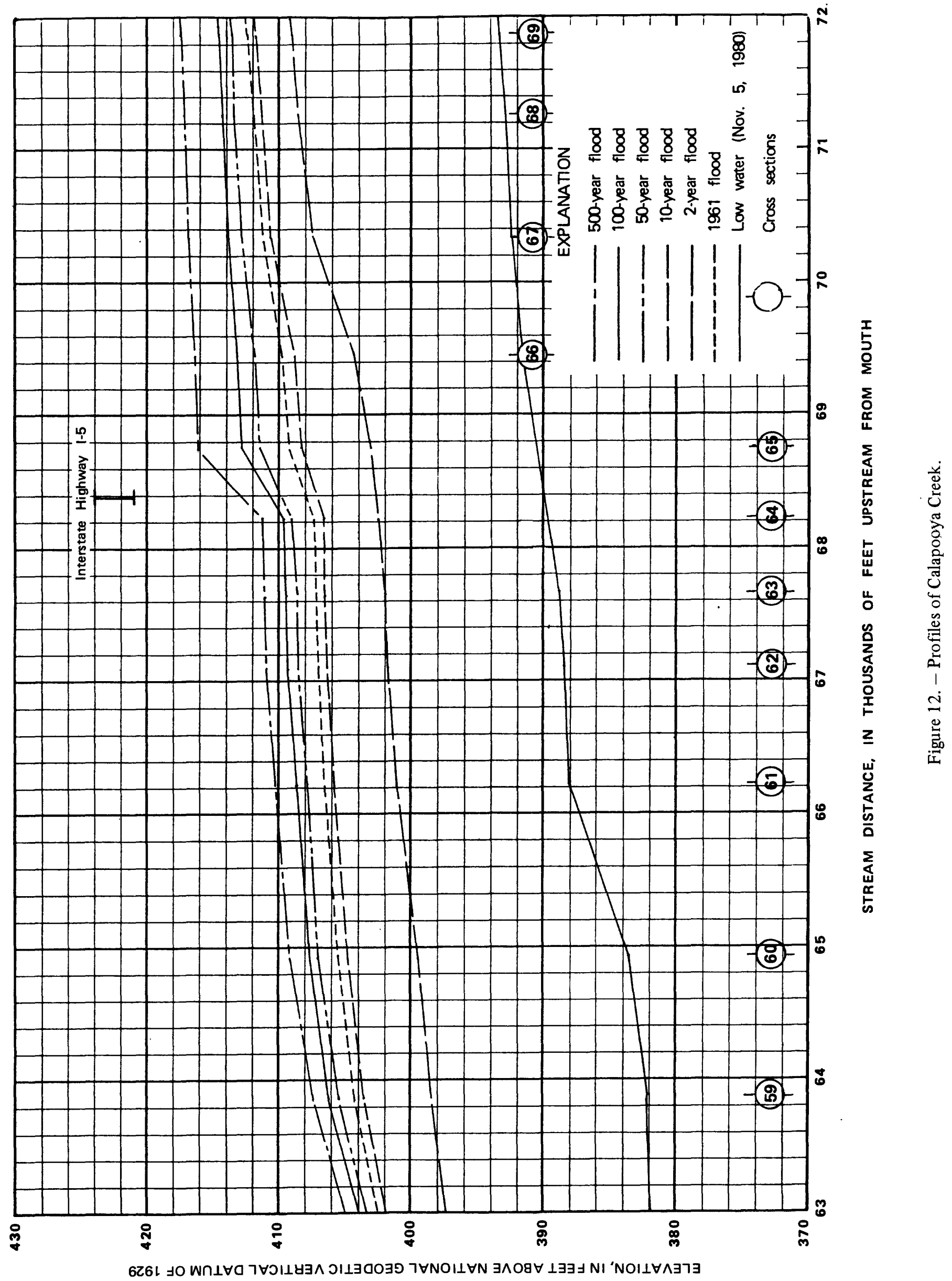




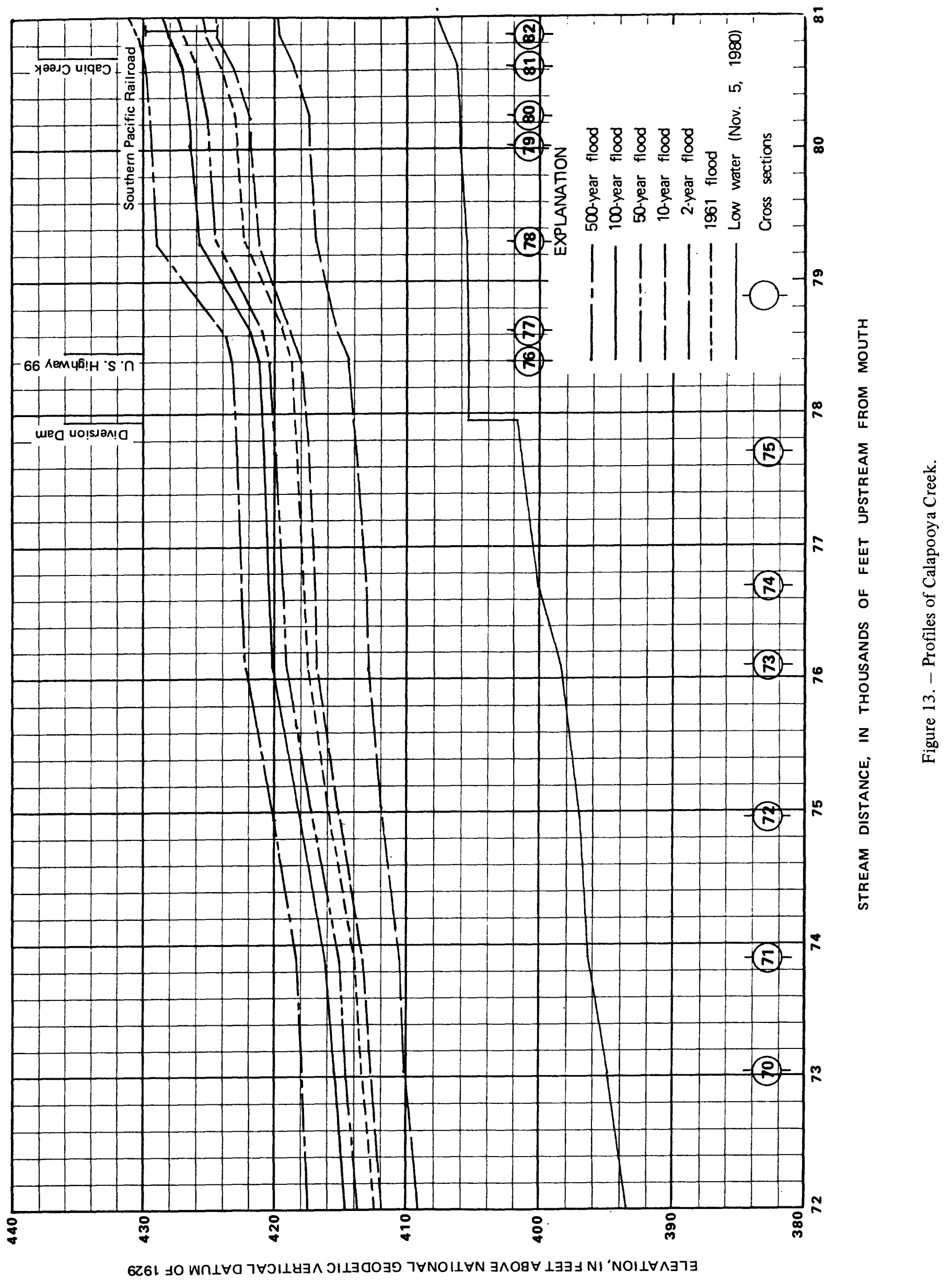




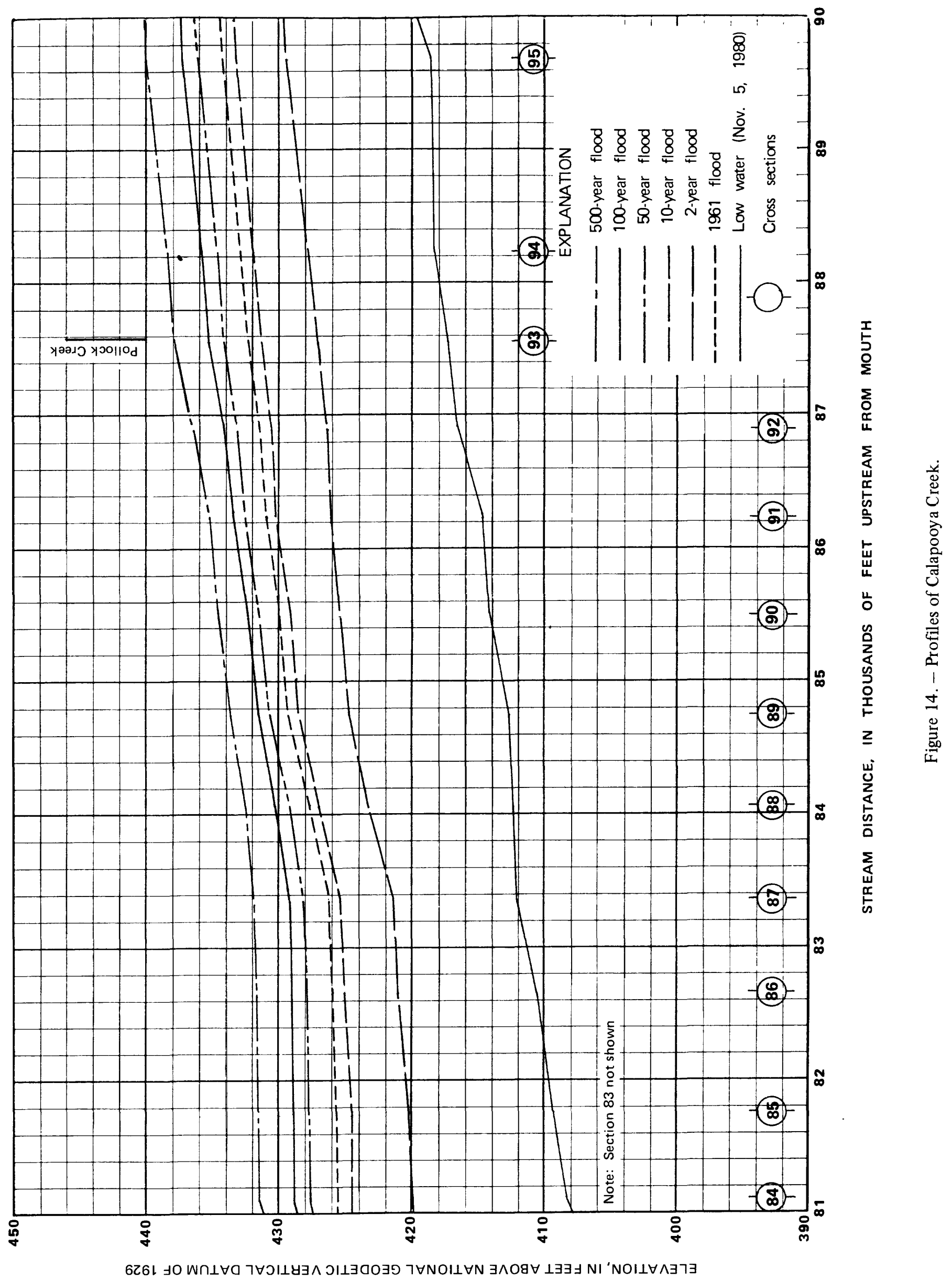




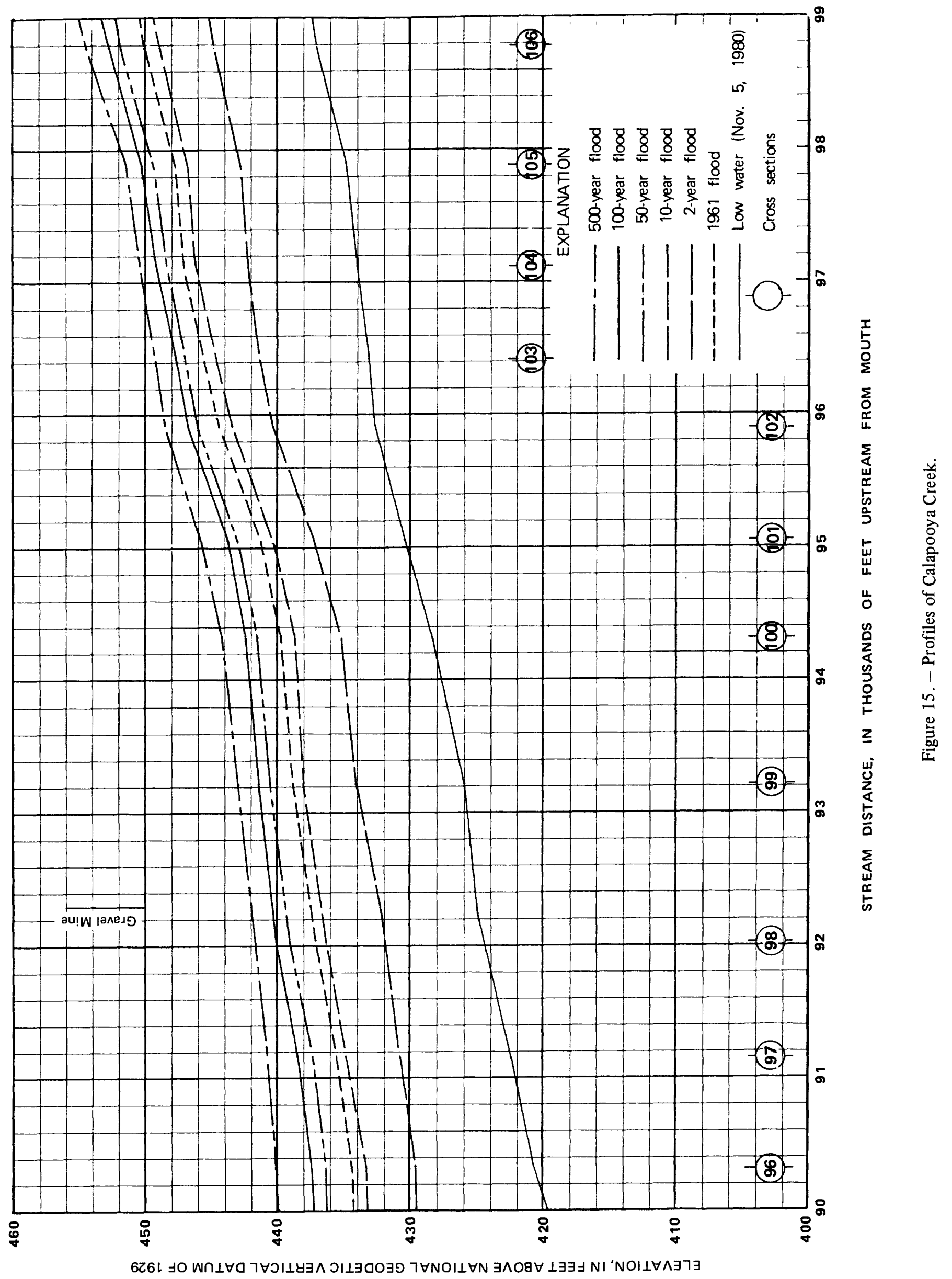




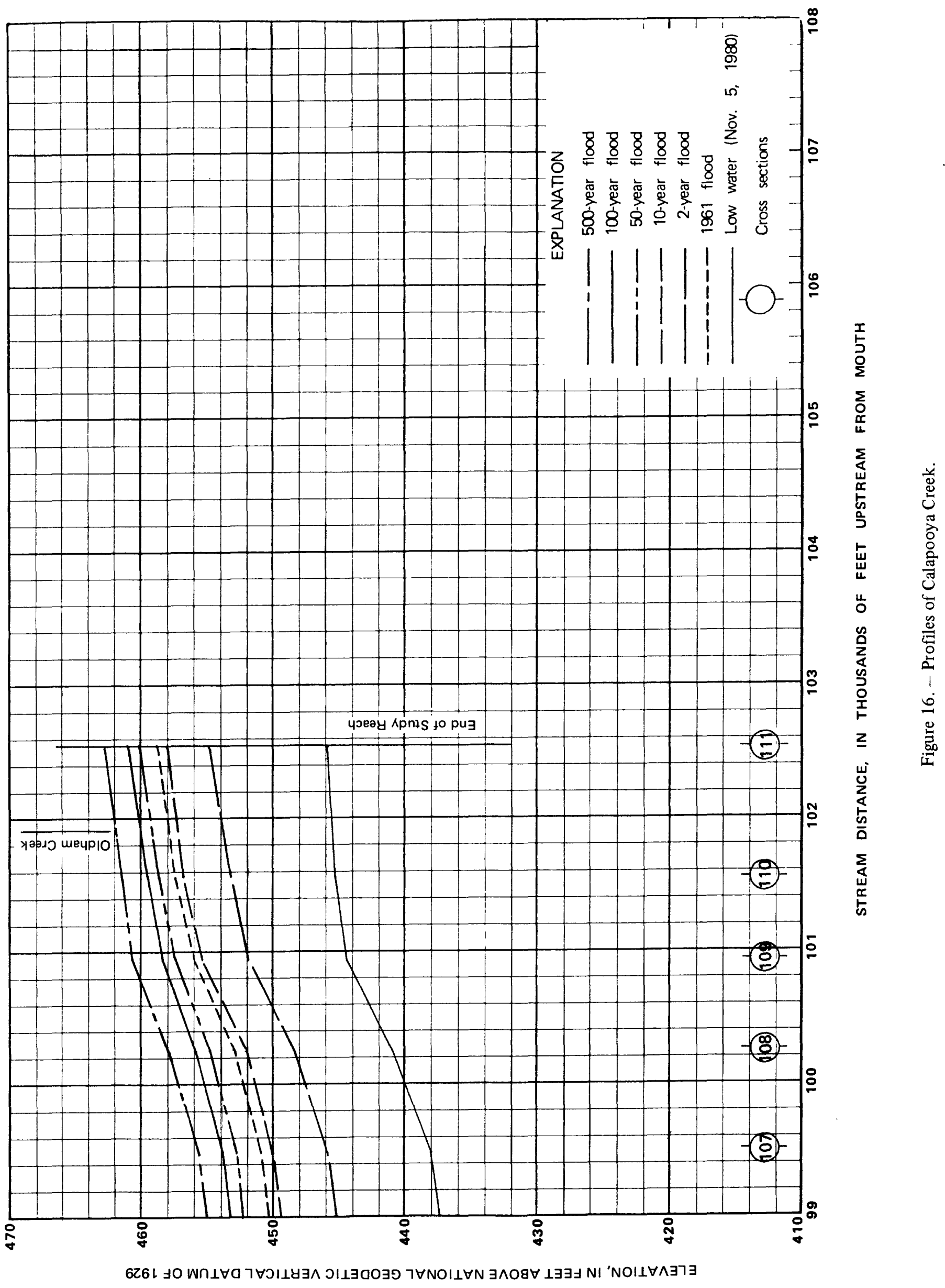

